\title{
Geology, petrology, U-Pb (shrimp) geochronology of the Morrinhos granite - Paraguá terrane, SW Amazonian craton: implications for the magmatic evolution of the San Ignácio orogeny
}

Geologia, petrologia, geocronologia U-Pb (shrimp) do Granito Morrinhos -terreno Paraguá, SW do Cráton Amazônico: implicações sobre a evolução magmática da orogenia san ignácio

\author{
Ohana França ${ }^{1,4,6 *}$, Amarildo Salina Ruiz ${ }^{1,2,4,6}$, Maria Zélia Aguiar de Sousa ${ }^{1,3,4,6}$, \\ Maria Elisa Fróes Batata ${ }^{4}$, Jean-Michel Lafon ${ }^{5,6}$
}

\begin{abstract}
Morrinhos granite is a batholith body that is slightly elongated in the NNW direction and approximately $1,140 \mathrm{~km}^{2}$ long; it is located in the municipality of Vila Bela da Santíssima Trindade of the state of Mato Grosso, Brazil, in the Paraguá Terrane, Rondonian-San Ignácio Province, in the SW portion of the Amazonian Craton. This intrusion displays a compositional variation from tonalite to monzogranite, has a medium to coarse inequigranular texture and is locally porphyritic; biotite is the predominant mafic in one of the facies, and hornblende is predominant in the other, with both metamorphosed into the greenschist facies. The studied rocks characterize an intermediate to acidic sequence that was formed by a subalkaline magmatism; the series is alkali-calcic to metaluminous to slightly peraluminous, and the rocks evolved through fractioned crystallization mechanisms. The structural data show two deformation phases represented by penetrative foliation $\left(S_{1}\right)$ and open folds $\left(\mathrm{D}_{2}\right)$, and both phases were most likely related to the San Ignácio Orogeny. The geochronological (U-Pb SHRIMP) and isotopic (Sm-Nd) investigations of these rocks indicated a crystallization age of $1350 \pm 12 \mathrm{Ma}$, $\mathrm{T}_{\mathrm{DM}}$ of approximately $1.77 \mathrm{Ga}$ and $\varepsilon \mathrm{Nd}_{(1.35)}$ with a negative value of -2.57 , suggesting that their generation was related to a partial melting process of a Paleoproterozoic (Statherian) continental crust. The results herein indicate that the Morrinhos granite was generated in a continental magmatic arc in a late- to post-orogenic stage of the San Ignácio Orogeny, and it can be recognized as belonging to the Pensamiento Intrusive Suite.
\end{abstract}

KEYWORDS: Morrinhos Granite; Pensamiento Intrusive Suite; San Ignácio Orogeny.
RESUMO: O Granito Morrinhos é um corpo batolítico levemente alongado segundo a direção $N N W$, de aproximadamente $1.140 \mathrm{~km}^{2}$, localizado no município de Vila Bela da Santíssima Trindade, estado de Mato Grosso. Situa-se no Terreno Paraguá, Província Rondoniana-San Ignácio, na porção SW do Cráton Amazônico. Essa intrusão exibe uma variação composicional entre tonalito a monzogranito, textura inequigranular média a grossa, localmente, porfiritica, tendo biotita como máfico predominante em uma das fácies e hornblenda na outra, ambas metamorfizadas na fácies xisto verde. As rochas estudadas caracterizam uma sequência intermediária a ácida formada por um magmatismo subalcalino, do tipo álcali-cálcico, metaluminoso a levemente peraluminoso evoluido por meio de mecanismos de cristalização fracionada. Dados estruturais exibem registros de duas fases deformacionais, representadas pela foliação penetrativa $\left(S_{1}\right)$ e dobras abertas $\left(D_{2}\right)$ ambas, provavelmente, relacionadas à Orogenia San Ignácio. A investigação geocronológica (U-Pb SHRIMP) e geoquímica isotópica $(S m-N d)$ dessas rochas indicaram, respectivamente, idade de cristalizaçâo $1.350 \pm 12 \mathrm{Ma}, T_{D M}$ em torno de $1,77 \mathrm{Ga}$ e valor negativo para $\varepsilon N d_{(1,35)}$ de $-2,57$, sugerindo uma geraçáo relacionada com processo de fusão parcial de uma crosta continental paleoproterozoica (estateriana). Os resultados aqui obtidos indicam que o Granito Morrinhos foi gerado em arco magmático continental, em estágio tardi a pós-orogênico, da Orogenia San Ignácio e permite reconhecê-lo como pertencente à Suite Intrusiva Pensamiento.

PALAVRAS-CHAVE: Granito Morrinhos; Suite Intrusiva Pensamiento; Orogenia San Ignácio.

\footnotetext{
${ }^{1}$ Graduate Program in Geosciences, Instituto de Ciências Exatas e da Terra, Universidade Federal de Mato Grosso - UFMT. Cuiabá (MT), Brasil. Emails: ohana.geo@gmail.com; asruiz@gmail.com; mzaguiar@terra.com.br

${ }^{2}$ Department of General Geology, Instituto de Ciências Exatas e da Terra, Universidade Federal de Mato Grosso - UFMT, Cuiabá (MT), Brasil. ${ }^{3}$ Department of Mineral Resources, Instituto de Ciências Exatas e da Terra, Universidade Federal de Mato Grosso - UFMT, Cuiabá (MT), Brasil. ${ }^{4}$ Research Group in Crustal and Tectonic Evolution, Guaporé, Universidade Federal de Mato Grosso - UFMT, Cuiabá (MT), Brasil. E-mail: elisabatata@bol.com.br ${ }^{5}$ Laboratory of Isotope Geology, Institute of Geosciences, Universidade Federal do Pará - UFPA, Belém (PA), Brasil. E-mail: lafonjm@ufpa.br ${ }^{6}$ National Institute of Science and Geosciences Technology of the Amazon - GEOCIAM, Belém (PA), Brasil. *Corresponding author
}

Manuscrito ID 30069. Recebido em: 17/12/2013. Aprovado em: 01/09/2014. 


\section{INTRODUCTION}

The Pensamiento Granitoid Complex/Pensamiento Intrusive Suite (PIS), which is located in the southwestern portion of the Amazonian Craton, represents a significant and voluminous acid plutonic magmatism of Ectasian age and is classified as syn- to post-kinematic according to its placement in relation to the San Ignácio Orogeny (Litherland et al. 1986; Ruiz 2005; Ruiz et al. 2009; Matos et al. 2009; Bettencourt et al. 2010).

The PIS is included in the Paraguá Terrane (PT), which extends from western Bolivia to the far west of Brazil, and is described as an allochthonous crustal fragment that was added to the margin of the Amazonian ProtoCraton from the Mesoproterozoic to the Neoproterozoic, during the San Ignácio Orogeny (1.40 to $1.28 \mathrm{Ga})$ and inserted in the Rondonian-San Ignácio Province.

The Morrinhos Granite (MG) is named after the homonymous community located near the Vila Santa Clara do Monte Cristo, Ponta do Aterro, in the municipality of Vila Bela da Santíssima Trindade of southwestern Mato Grosso State, along the Brazil-Bolivia border, where the rocks that compose the PT occur. The MG is intrusive in orthogneisses of the Chiquitania Metamorphic Complex, Serra do Baú Intrusive Suite, which is on the eastern edge of the PT.

This granite was preliminarily described by França et al. (2013) and is now being discussed in detail in the present study, which consists of data obtained from systematic geological mapping on a 1:300,000 scale, petrographic characterizations, and geochemical, geochronological (U-Pb/SHRIMP) and isotopic (Sm-Nd) analyses that were used to define the age of placement of the intrusion, magma petrogenesis and tectonic setting where it was likely generated. The results will contribute to the knowledge of the magmatic and deformational evolution related to the San Ignácio Orogeny in Brazilian territory.

\section{REGIONAL GEOLOGICAL BACKGROUND}

The Amazonian Craton, which is located on the South American Platform, represents one of the main Precambrian geotectonic entities of the world and is an outcropping, mainly in the Guianas and Central Brazilian shields, that is partially covered by Quaternary sediments.

According to Bettencourt et al. (2010; Fig. 1), the Rondonian-San Ignácio Province is an orogen established through successive volcanic arc accretions, oceanic basin closure and microcontinent-continent collision. The province consists of the Jauru (1.78 to $1.42 \mathrm{Ga}$ ), Paraguá (1.74 to $1.32 \mathrm{Ga}$ ) and Rio Alegre (1.51 to $1.38 \mathrm{Ga})$ terranes and the Alto Guaporé Belt (1.42 to $1.34 \mathrm{Ga}$ ).

The PT was initially called the Paraguá Craton by Litherland et al. (1986) and described by Boger et al. (2005) as an allochthonous crustal fragment that was accreted to the edge of the Amazonian Proto-Craton during the Mesoproterozoic or Neoproterozoic. According to the latter, the collision and agglutination of this terrane to the Amazonian Craton occurred during the Sunsás Orogeny (1.0 to $0.9 \mathrm{Ga}$ ). Ruiz et al. (2011) interpreted the PT as a crustal fragment $(1.8$ to $1.6 \mathrm{Ga})$ reworked into two orogenic cycles: the San Ignácio Orogeny (1.4 to $1.3 \mathrm{Ga}$ ) and Sunsás Orogeny $(1.0$ to $0.9 \mathrm{Ga})$. This terrane hosts Paleoproterozoic units from prior to the San Ignácio Orogeny; these units are the Lomas Manechis Granulitic Complex, San Ignácio Schist Group and Chiquitania Gneissic Complex/Serra do Baú Intrusive Suite and Mesoproterozoic intrusives of the Pensamiento Granitoid Complex/PIS (Litherland et al. 1986; Matos et al. 2009; Bettencourt et al. 2010; Jesus et al. 2010; Ruiz et al. 2011; Ruiz et al. 2012; Nalon et al. 2013).

The Pensamiento Granitoid Complex in Bolivian territory was divided by Litherland et al. (1986) into syn- to late-kinematic granites $(1.37$ to $1.35 \mathrm{Ga}$; Matos et al. 2009) and late- to post-kinematic granites (1.34 Ga; Matos et al. 2009), and represents the main magmatic product related to the San Ignácio Orogen (Ruiz 2005; Ruiz et al. 2009; Matos et al. 2009; Bettencourt et al. 2010).

Table 1 presents the geochronological data recorded in research from recent years, which includes units related to the San Ignácio Orogeny, that form the Pensamiento Granitoid Complex in Bolivian territory and are correlated with the PIS in Brazil.

\section{FIELD AND PETROGRAPHIC ASPECTS}

The MG highlighted in this work is characterized as an elongated intrusion of approximately $1,140 \mathrm{~km}^{2}$ with its major axis oriented in the NNW direction. It has tectonic contact with the Lomas Manechis Granulitic Complex and it is covered, at its ends, by unconsolidated Quaternary sediments from the Guaporé Formation (Fig. 2).

The rocks of the MG form hills (Fig. 3A) and rocky pavements which outcrop mainly in recessed areas, wetlands or bays. Occasionally, the MG exhibits relic 


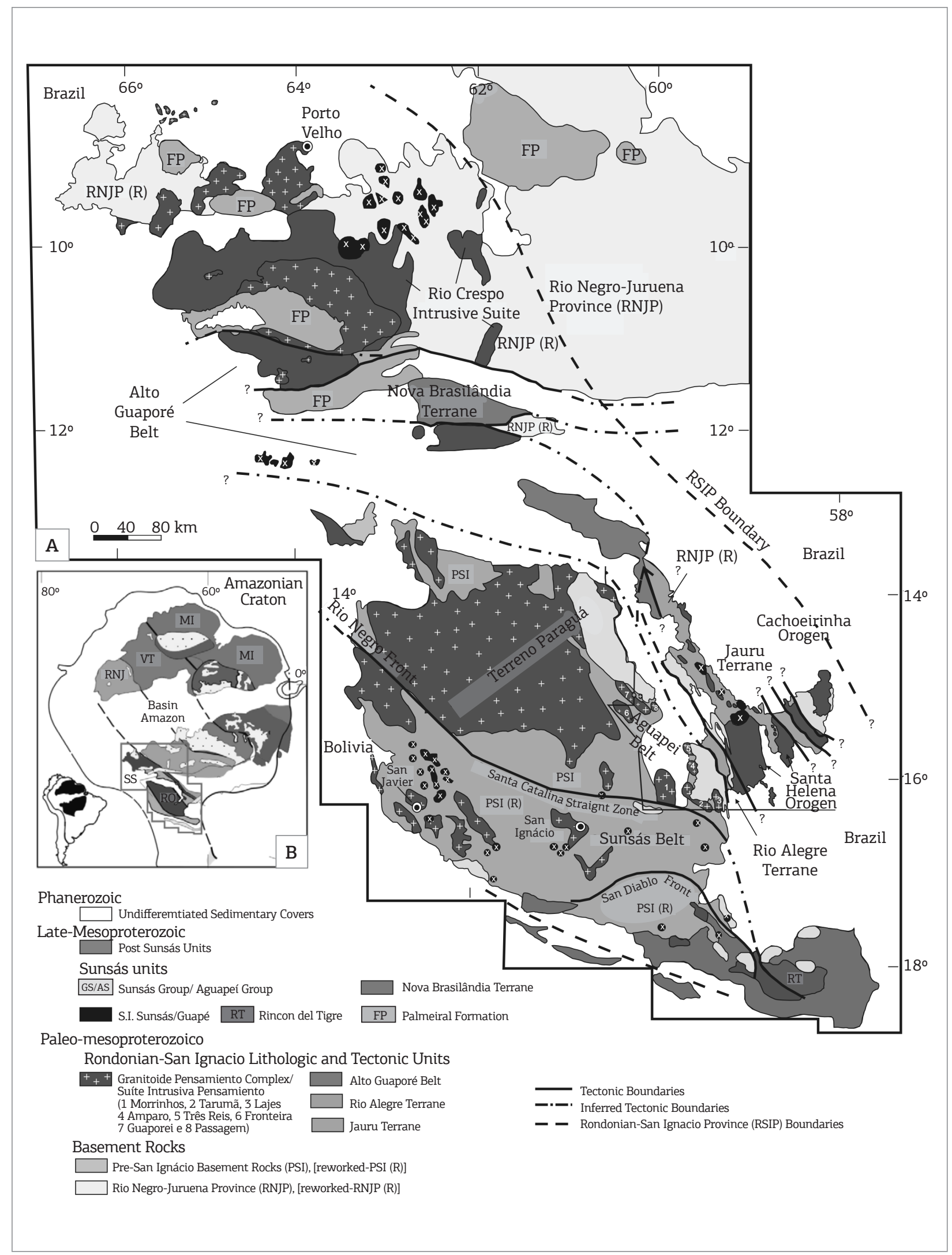

Figure 1. (A) Tectonic map of the Rondonian-San Ignácio Province, southwestern Amazonian Craton. (B) Main provinces of the Amazonian Craton. Extracted and modified from Bettencourt et al. (2010). 
Table 1. Geochronological data from the granitoids of the Pensamiento Granitoid Complex/PIS

\begin{tabular}{|c|c|c|c|c|c|c|c|c|c|c|}
\hline \multirow{2}{*}{\multicolumn{2}{|c|}{ LithologicUnits }} & \multirow{3}{*}{$\begin{array}{c}\text { References } \\
\text { Age (Ma) } \\
\begin{array}{c}\text { Litherland et al. } \\
(1986)\end{array}\end{array}$} & \multirow{3}{*}{$\begin{array}{c}\text { U-Pb } \\
\text { Age (Ma) } \\
-\end{array}$} & \multirow{3}{*}{\begin{tabular}{|c|}
$\mathrm{Pb}-\mathrm{Pb}$ \\
Age (Ma) \\
- \\
\end{tabular}} & \multicolumn{2}{|c|}{$\mathrm{Rb}-\mathrm{Sr}$} & \multicolumn{3}{|c|}{ Sm-Nd } & \multirow{3}{*}{$\begin{array}{c}\text { K-Ar (Ma) } \\
\text { (B) } 1326 \pm 19 \\
\text { (M) } 1268 \pm 20\end{array}$} \\
\hline & & & & & \multirow{2}{*}{$\begin{array}{c}\mathrm{Sr}^{87} / \mathrm{Sr}^{86} \\
-\end{array}$} & \multirow{2}{*}{$\begin{array}{c}\mathrm{T}_{\text {(DM) }}(\mathrm{Ga}) \\
- \\
\end{array}$} & \multirow{2}{*}{$\begin{array}{c}\varepsilon N d(0) \\
-\end{array}$} & \multirow{2}{*}{$\begin{array}{c}\varepsilon N d(t) \\
-\end{array}$} & \multirow{2}{*}{$\begin{array}{c}\text { Age (Ma) } \\
-\end{array}$} & \\
\hline \multirow{11}{*}{ 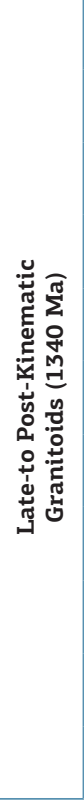 } & Padre Eterno & & & & & & & & & \\
\hline & Orabayaya & $\begin{array}{c}\text { Litherland et al. } \\
\text { (1986) }\end{array}$ & - & - & (RT) $1283 \pm 33$ & 0.7058 & - & - & & - \\
\hline & \multirow{2}{*}{ Piso Firme } & $\begin{array}{c}\text { Litherland et al. } \\
\text { (1986) }\end{array}$ & - & - & (RT) $1325 \pm 45$ & 0.7044 & - & & & - \\
\hline & & $\begin{array}{l}\text { Matos et al. } \\
\text { (2009) }\end{array}$ & - & - & - & - & 1.59 & -7.99 & 2.32 & - \\
\hline & \multirow{2}{*}{ Diamantina } & $\begin{array}{c}\text { Litherland et al. } \\
\text { (1986) }\end{array}$ & - & - & (RT) $1391 \pm 70$ & 0.7004 & - & - & & - \\
\hline & & $\begin{array}{l}\text { Matos et al. } \\
\text { (2009) }\end{array}$ & (Z) $1340 \pm 20$ & - & - & - & $1.65-1.92$ & $-16.6--8.51$ & $-1.25-0.38$ & \\
\hline & \multirow{2}{*}{ San Cristobal } & $\begin{array}{l}\text { Litherland et al. } \\
\text { (1986) }\end{array}$ & - & - & - & - & - & - & & (B) $1296 \pm 18$ \\
\hline & & $\begin{array}{l}\text { Matos et al. } \\
\text { (2009) }\end{array}$ & - & - & - & - & $1.58-1.59$ & $-6.28--5.87$ & $2.63-2.75$ & \\
\hline & Porvenir & $\begin{array}{l}\text { Matos et al. } \\
\text { (2009) }\end{array}$ & - & - & - & - & 1.74 & -6.89 & 1.48 & - \\
\hline & Lajes & $\begin{array}{l}\text { Geraldes } \\
(2000)\end{array}$ & (Z) $1310 \pm 34$ & - & - & - & 1.69 & - & 0.0 & - \\
\hline & Passagem & $\begin{array}{l}\text { Jesus et al. } \\
\text { (2010) }\end{array}$ & (Z) $1284 \pm 20$ & - & - & - & 1.60 & -10.56 & -7 & - \\
\hline \multirow{7}{*}{ 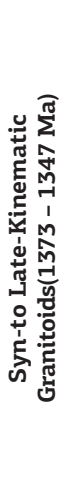 } & Florida & $\begin{array}{c}\text { Litherland et al. } \\
\text { (1986) }\end{array}$ & - & - & - & - & - & - & - & $\begin{array}{l}\text { (B) } 1380 \pm 19 \\
\text { (B) } 1244 \pm 27\end{array}$ \\
\hline & \multirow{2}{*}{ La Junta } & $\begin{array}{l}\text { Litherland et al. } \\
\text { (1986) }\end{array}$ & - & - & (RT) $1375 \pm 80$ & 0.7052 & - & - & - & - \\
\hline & & $\begin{array}{l}\text { Matos et al. } \\
\text { (2009) }\end{array}$ & (Z) $1347 \pm 21$ & - & - & - & $1.87-2.04$ & $-19.6--17.8$ & $-4.29--2.94$ & \\
\hline & San Martín & $\begin{array}{l}\text { Matos et al. } \\
\text { (2009) }\end{array}$ & (Z) $1373 \pm 20$ & - & - & - & 1.68 & -7.43 & 1.78 & - \\
\hline & Fronteira & Ruiz et al. (2012) & - & (Z) $1333 \pm 4$ & - & - & - & - & - & - \\
\hline & Guaporeí & $\begin{array}{l}\text { Nalon et al. } \\
\text { (2013) }\end{array}$ & - & (Z) $1314 \pm 2.5$ & - & - & 1.76 & -21.42 & -14 & - \\
\hline & Tarumã & $\begin{array}{c}\text { Comunicação } \\
\text { Verbal Matos } \\
\text { J. B. }\end{array}$ & (Z) $1377 \pm 5$ & - & - & - & 1.9 & -19.68 & -4.11 & - \\
\hline
\end{tabular}

(B) biotite. (M) muscovite. (Z) zircon and (RT) whole rock. *granitic bodies of Bolivian territory. ** granitic bodies of Brazilian territory.

magmatic flow structures in a N10E direction, with a width of approximately $1 \mathrm{~m}$ as well as dikes of granitic, fine-grained composition and enclaves.

This unit consists of leucocratic to mesocratic locally porphyritic rocks with an $\mathrm{M}$ index between 15 and 35\%, colors ranging from light gray to dark gray and pinkish gray, and a texture that is inequigranular medium to coarse. The main composition of these lithotypes consists of quartz, plagioclase, alkali feldspar, hornblende and biotite. The porphyritic samples are characterized by the presence of phenocrysts of plagioclase and alkali feldspars (orthoclase and microcline). The MG rocks are classified from tonalite to monzogranite; based on field and mineralogical features, the rocks are divided into two petrographic facies: hornblende-biotite tonalite (HBTF) and biotite granodiorite to monzogranite (BGMF).
The HBTF predominates in area size; however, it cannot be individualized.

Macroscopically, the HBTF (Fig. 3C) is characterized by mesocratic to leucocratic rocks (M: 35 to $25 \%$ ) that are light to dark gray, and consists of quartz, plagioclase, alkali feldspar (orthoclase and microcline), biotite and hornblende. The BGMF (Fig. 3D) is characterized by rocks that are pinkish gray with a lower color index (M: 15 to 20\%), with only biotite as an essential mafic mineral.

Under petrographic microscope, the HBTF rocks have a xenomorphic to hypidiomorphic inequigranular texture (Fig. 4A) that is medium to coarse and sometimes porphyritic, whereas the BGMF is predominantly xenomorphic (Fig. 5A). A large amount of hornblende and biotite aggregates characterize the HBTF (Fig. 4B), whereas biotite is the only mafic mineral present in the BGMF, 


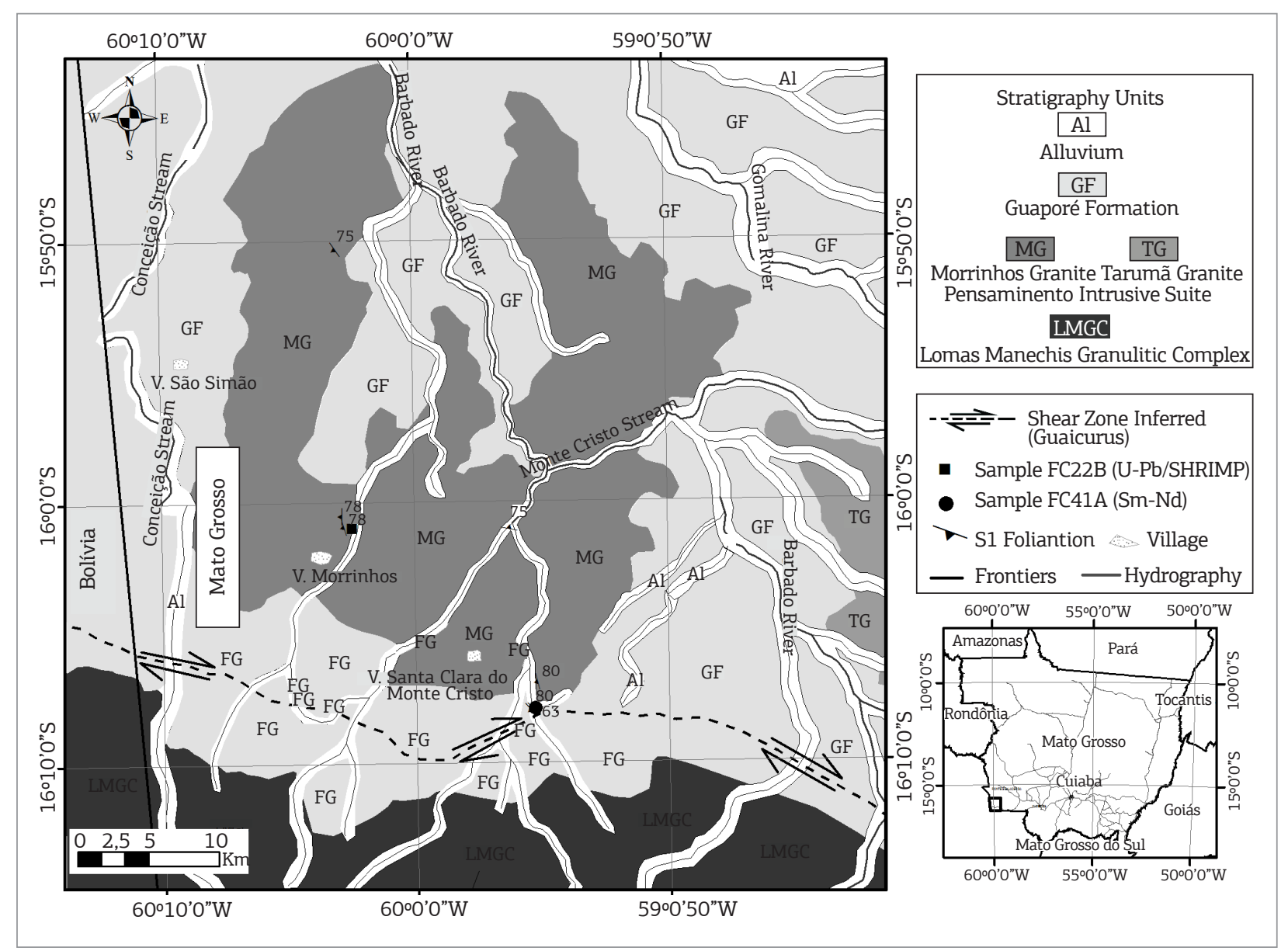

Figure 2. Geological map of the study area on a 1:300,000 scale.

often as aggregates. The primary accessory minerals are titanite, apatite, zircon, rutile, allanite and opaques, and the hydrothermal alteration products, which are associated with low-grade metamorphism of the greenschist facies, are represented by sericite, epidote, clay minerals, chlorite, muscovite, titanite and opaques.

The plagioclase in both facies occurs as anhedral to subhedral tabular crystals with albite, Carlsbad and pericline twinning, which may be combined with apatite, biotite, quartz and opaques inclusions. Based on the MichelLevy statistical method, the plagioclase is classified from andesine in the less differentiated tonalites to albite in the monzogranites. The plagioclase often shows normal zoning where the most calcic core is slightly altered in the HBTF, whereas two generations of plagioclase are distinguished in the BGMF (Fig. 5B): a primary generation represented by heavily altered crystals and a post-magmatic generation represented clear recrystallized crystals of albitic composition. The plagioclase exhibits a myrmekitic texture at the interface with alkali feldspars, and it is arranged as small crystals associated with tiny grains of quartz. Alteration processes, such as saussuritization, sericitization and argillization, are observed in the described facies and are shown in the locally altered fibrous muscovite crystals.

Alkali feldspars are represented by orthoclase and microcline and occur as subhedral to anhedral tabular crystals; in the BGMF, they also appear as phenocrysts. Both facies show Carlsbad twinning or combined (albite + pericline) twinning, and are partially sericitized or argillized. In general, they appear perthitic, both in venules or grains/droplets, and may exhibit graphic intergrowths as well as inclusions of apatite, biotite and opaques.

Quartz is found in the interstitial anhedral crystals as subgrains or recrystallized aggregates, and it is also found with a vermicular habit intergrown with plagioclase and alkali feldspar. The intracrystalline quartz deformation is marked by undulatory extinction, lamellae and deformation bands and subgrains.

Biotite occurs in subhedral lamellae, blades and platelets with light-brown to dark-brown pleochroism, and it can be isolated, formed into aggregates or included 

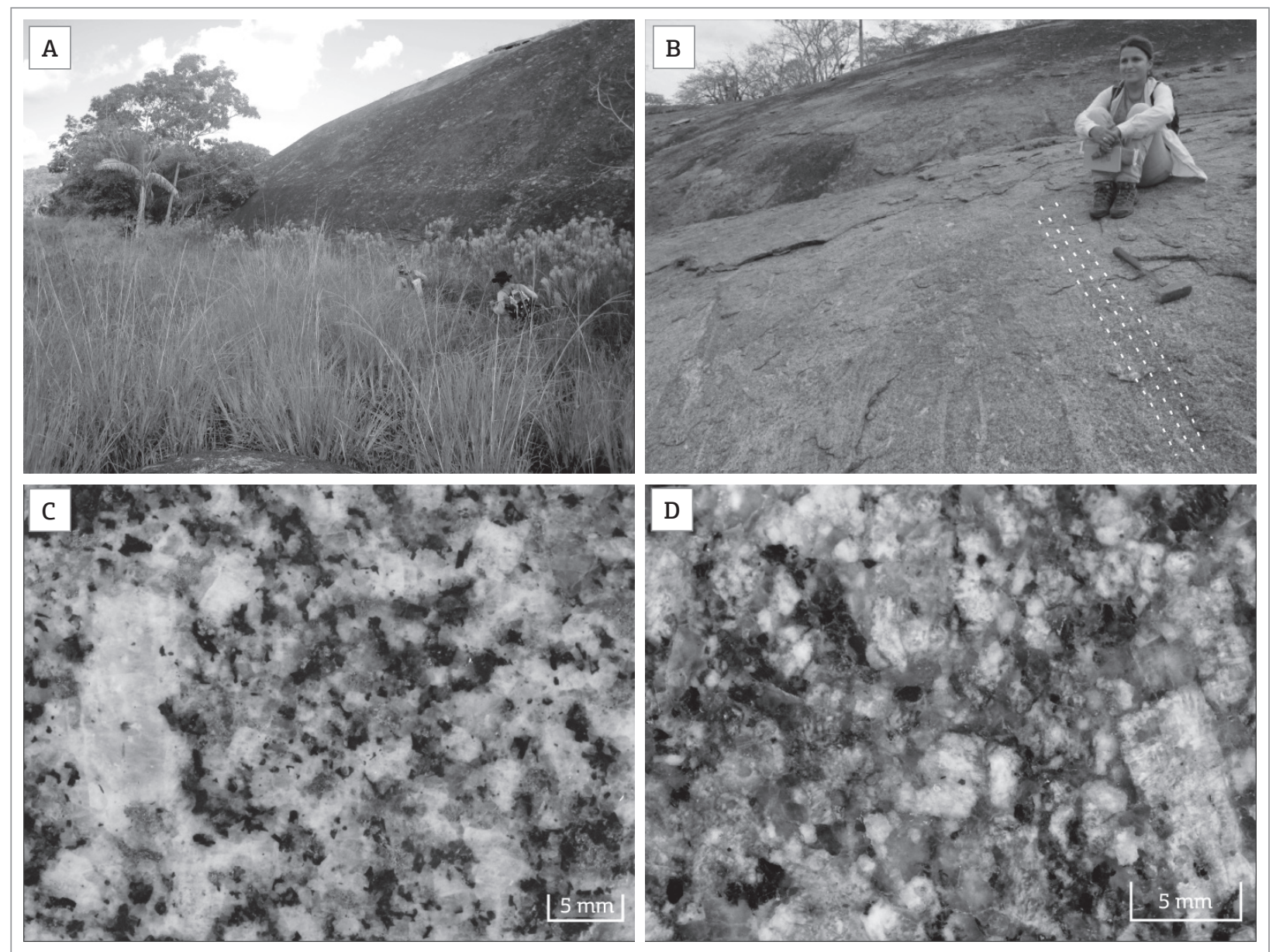

Figure 3. Field and petrographic aspect of the MG. (A) Geomorphological aspect of floodplain occurrences. (B) oriented mineralogical fabric detail. (C) HBTF macroscopic aspect with plagioclase phenocrysts in an inequigranular matrix. (D) BGMF macroscopic aspect of the xenomorphic inequigranular texture with biotite as the only essential mafic.

in feldspars. The biotite is usually associated with the hornblende, titanite and opaques in the HBTF rocks, and it shows a partial alteration into chlorite, muscovite (Fig. 4D) and opaque minerals. Biotite occasionally includes rutile needles characterizing a sagenitic texture and euhedral to subhedral zircon crystals that forming pleochroic halos in the biotite.

Amphibole is represented by the magmatic hornblende and only found in the HBTF. Amphibole occurs in anhedral grains and subhedral crystals with olive-green to brown pleochroism and forms mafic aggregates; it subordinately exhibits sector twinning, drop-like quartz texture and apatite inclusions. Amphibole is partially observed as altered into chlorite, biotite and opaque minerals.

Titanite is represented by two different generations: one that is formed by anhedral to subhedral crystals of rhombohedral habit with edging of opaque minerals, characterizing a coronitic texture (Fig. 5C), and another that is defined by poikilitic, orange, anhedral (Fig. 4C) grains and associated with mafic minerals.
Apatite is a primary accessory mineral that occurs in a prismatic or acicular habit, and it is indiscriminately included in feldspars and mafic minerals. Zircon shows typical bipyramidal prismatic habits, is sometimes subhedral and is most often associated with mafics, where it develops pleochroic halos. Rutile occurs with an acicular habit, it is included in biotite and forms a sagenitic texture (Fig. 5D). Allanite is a primary accessory appearing in tiny metamictic grains of yellow color (Fig. 5E), and it is associated with epidote. Opaques can be primary minerals that occur in isolated euhedral/subhedral crystals or secondary minerals of biotite, hornblende and titanite alterations.

Epidote consists of microgranular aggregate associated with plagioclase alterations. The clay minerals are products of the alteration of feldspars and form a thin blurred mass with tiny blades of sericite that are difficult to distinguish under the microscope. Chlorite occurs with fibrous to fibro-radiated habit as a biotite and hornblende alteration. The secondary biotite is derived from hornblende and is found associated with chlorite. 


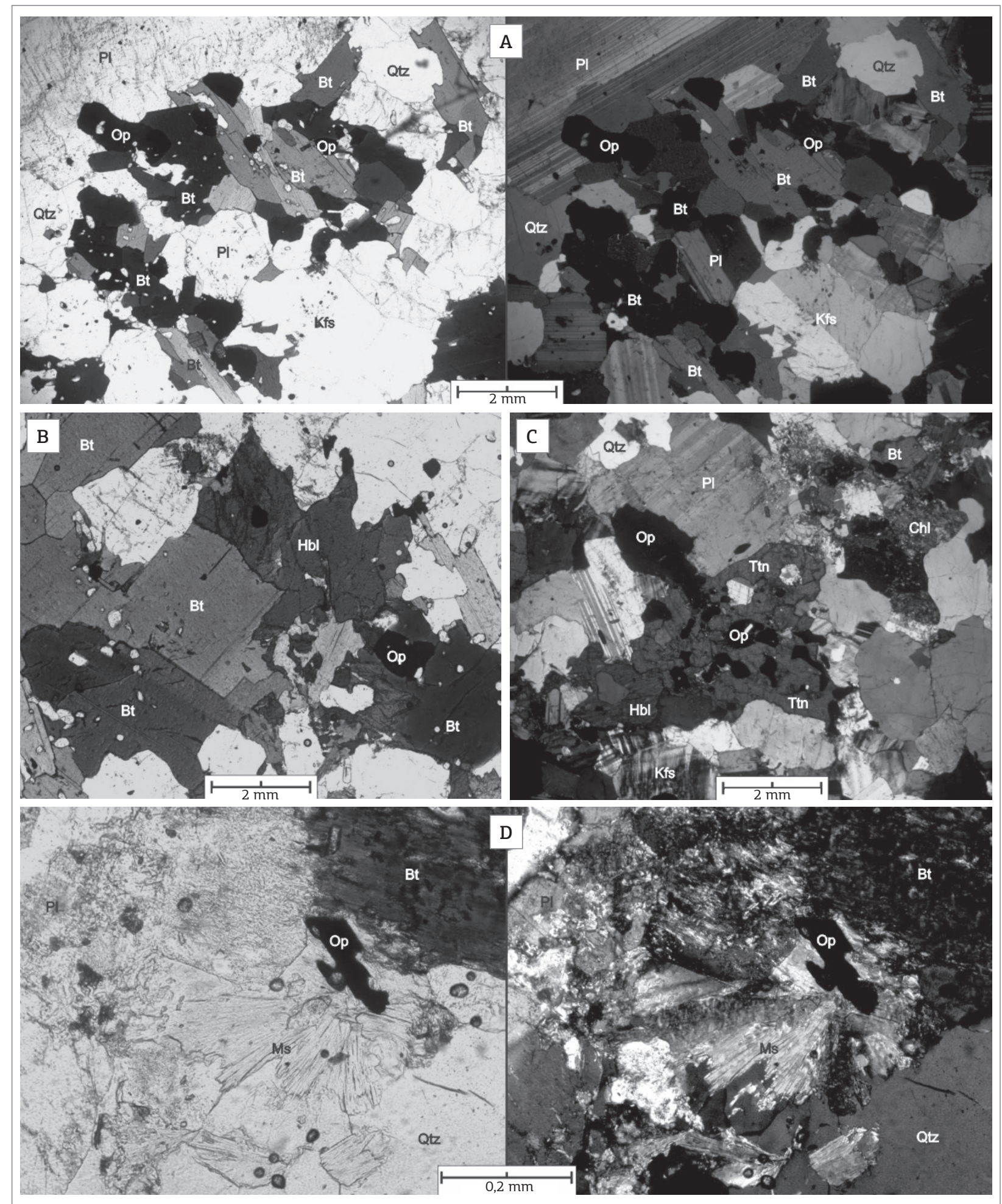

Figure 4. Photomicrographs of rocks from the MG hornblende-biotite tonalite facies showing the following: (A) inequigranular xenomorphic to hypidiomorphic texture formed by plagioclase, alkali feldspar and mafic aggregate, consisting of biotite with drop-like quartz texture and opaque minerals. (B) association with subhedral hornblende, biotite blades and opaque minerals, all with drop-like quartz texture. (C) mafic aggregate formed by hornblende, biotite/alteration chlorite, poikiloblast of titanite and opaque minerals. (D) partially chloritized biotite and fibro-radiated aggregate of secondary muscovite. Parallel polarizers are to the left, and cross-polarizers are to the right. 

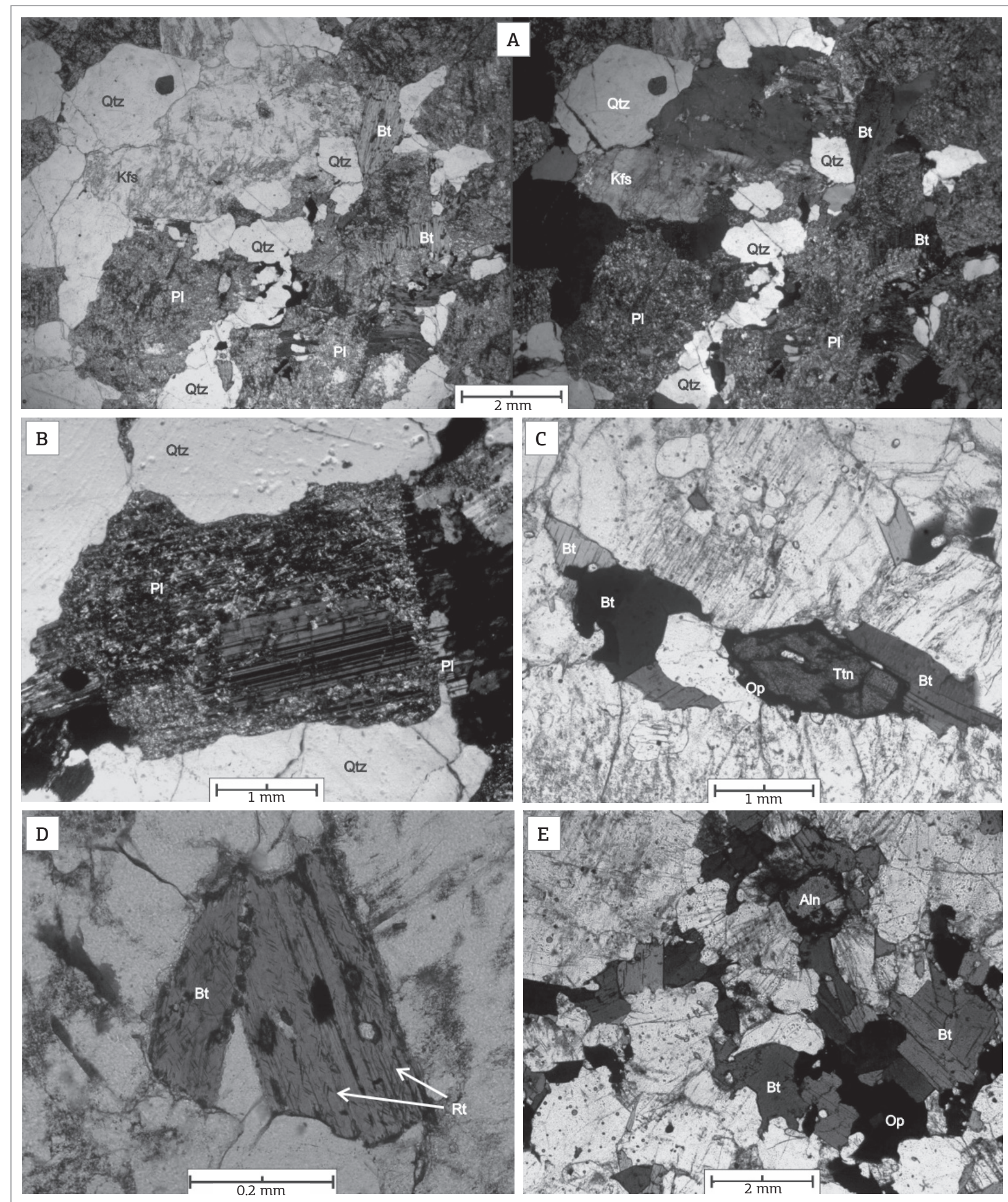

Figure 5. Photomicrographs of the rocks from the MG biotite granodiorite to monzogranite facies showing the following: (A) xenomorphic texture and sharp distinction between quartz, clear alkali feldspar and intensely saussuritized plagioclase and blades of partially chloritized biotite. (B) two generations of plagioclase: the primary generation represented by intensely saussuritized crystals and the secondary generation formed by neocrystallized and clear crystals. (C) rhombohedral crystal of titanite with coronitic texture formed by an opaque mineral. (D) biotite with acicular rutile inclusions characterizing a sagenitic texture. (E) aggregate of biotite blades, opaque minerals and metamictic allanite grain. Parallel polarizers are to the left, and cross-polarizers are to the right $(A)$; cross polarizers in (B) and parallel polarizers in (C), (D) and (E). 


\section{DEFORMATIONAL ASPECTS}

The conventions adopted for the organization of information related to the MG deformation were as follows: (Sn) to denote foliation, (Ln) to denote lineation, (Dn) to denote folding and (Fn) to denote the deformation phase. In each of the symbols, the letter $\mathrm{n}$ is an index $(\mathrm{n}=1,2 \ldots)$ according to the related deformation phase. The attitudes of the structures are shown in azimuth notation, for example, 120/45, where the first value indicates the direction of the bearing or strike and the second value is the dip or plunge value.

From the analysis of the structures and tectonic textures, the structural elements generated in two deformational phases $\left(\mathrm{F}_{1}\right.$ and $\left.\mathrm{F}_{2}\right)$ were identified.

The main deformation phase $\left(\mathrm{F}_{1}\right)$ affects the entire $\mathrm{MG}$ and is responsible for the development of penetrative foliation $\left(\mathrm{S}_{1}\right)$ with a preferential attitude at approximately 240/80 (Fig. 6A). The $S_{1}$ foliation is defined by the planar fabric provided by the preferential arrangement of the minerals (micas) and prismatic minerals (plagioclase and alkali feldspar) as well as their discrete flattening (Fig. 7). The $S_{1}$ tectonic foliation is arranged according to the major length of the batholith (NNW) and usually appears faint, although there are sites with higher intensity, indicating a heterogeneous deformation distribution.

The phase $\left(\mathrm{F}_{2}\right)$ is defined by the formation of open folds $\left(D_{2}\right)$ designed by penetrative foliation $\left(S_{1}\right)$ with axial planes that have dips of approximately $80^{\circ}$ toward the azimuth, $350 \mathrm{Az}$ (Fig. 6B). Discrete ductile shear zones $\left(S_{2}\right)$ are parallel to the axial plane of the $\mathrm{D}_{2}$ folds and produce the local transposition of tectonic foliation $\left(S_{1}\right)$ (Fig. 8).

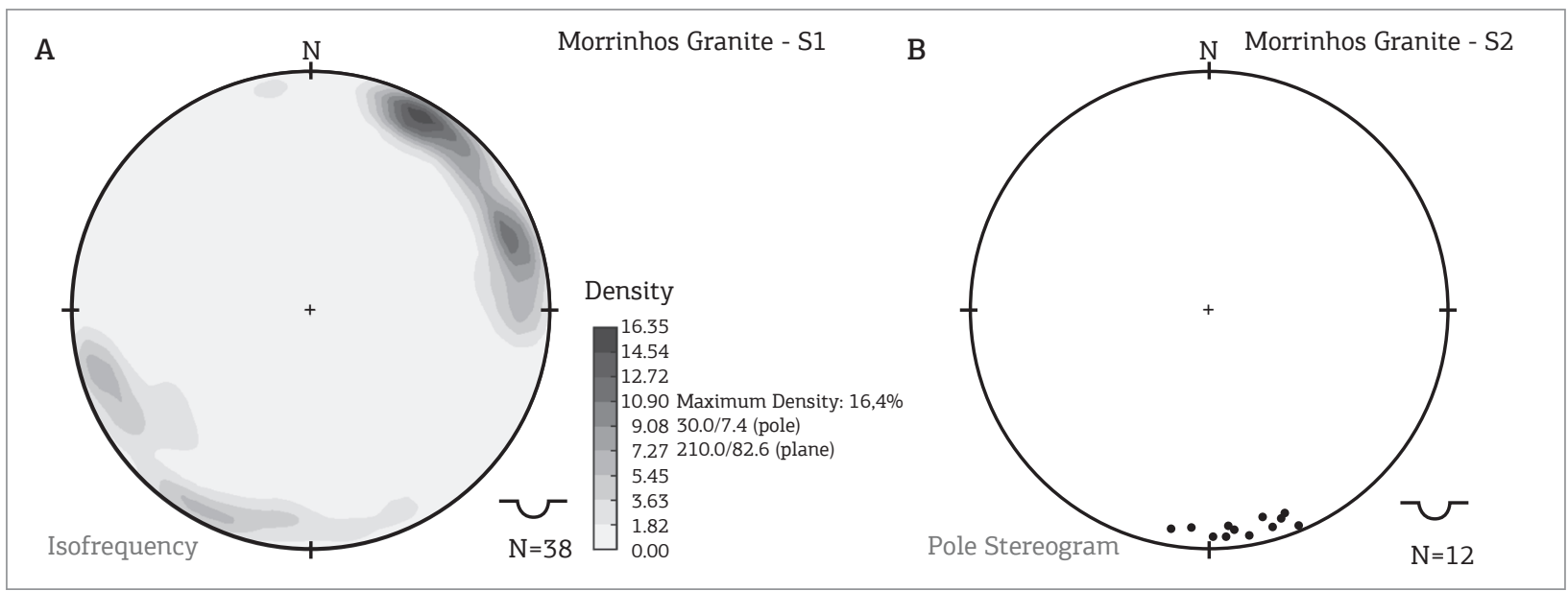

Figure 6. Isofrequency and polar stereograms of the MG representing the measurements related to the foliation $\left(\mathrm{S}_{1}\right)$ and shear zones $\left(\mathrm{S}_{2}\right)$ according to a lower-hemisphere projection. The $\mathrm{S}_{1}$ foliation exhibits a preferential concentration at approximately $240 / 80 \mathrm{Az}$ and shear zones $\left(\mathrm{S}_{2}\right)$, which show a maximum concentration at 350/82 Az.

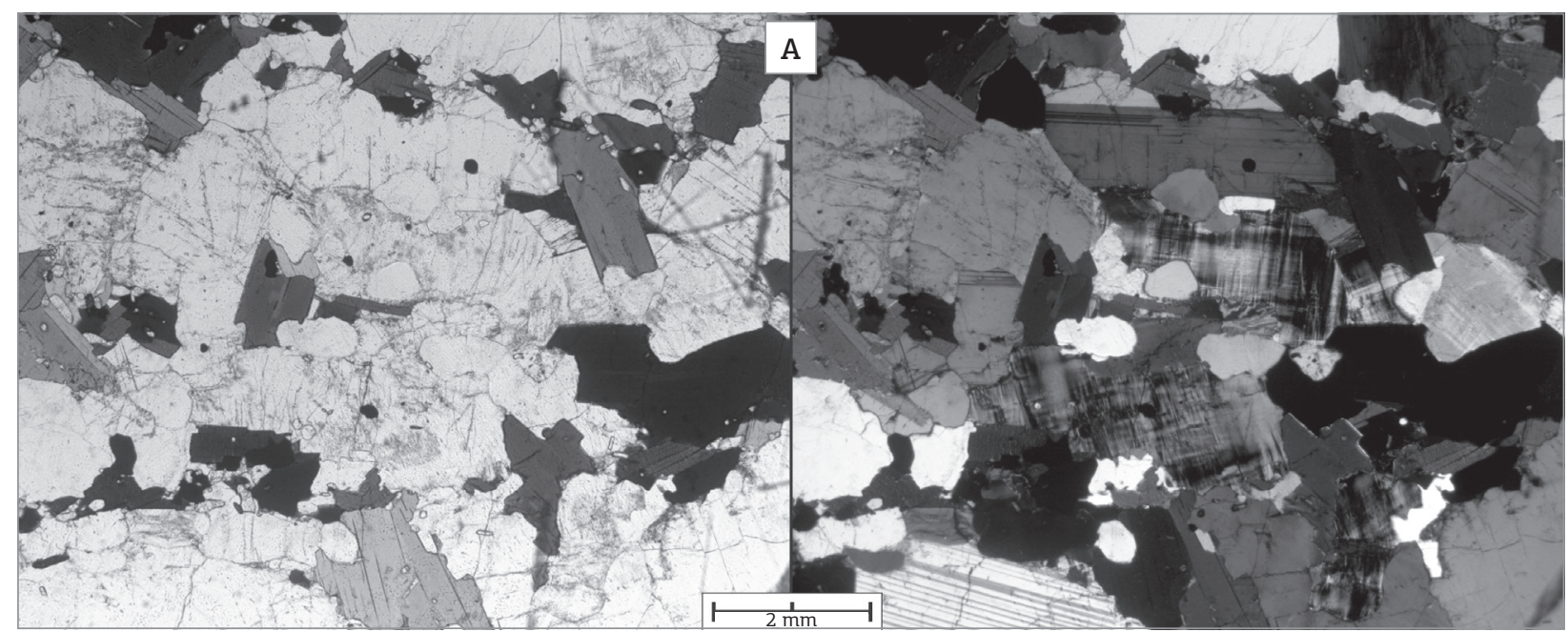

Figure 7. Photomicrograph of the MG rocks showing foliation $\left(\mathrm{S}_{1}\right)$ provided by the preferential arrangement of the minerals (micas) and prismatic minerals (plagioclase and alkali feldspar) as well as their discrete flattening. Parallel polarizers are to the left, and cross-polarizers are to the right. 


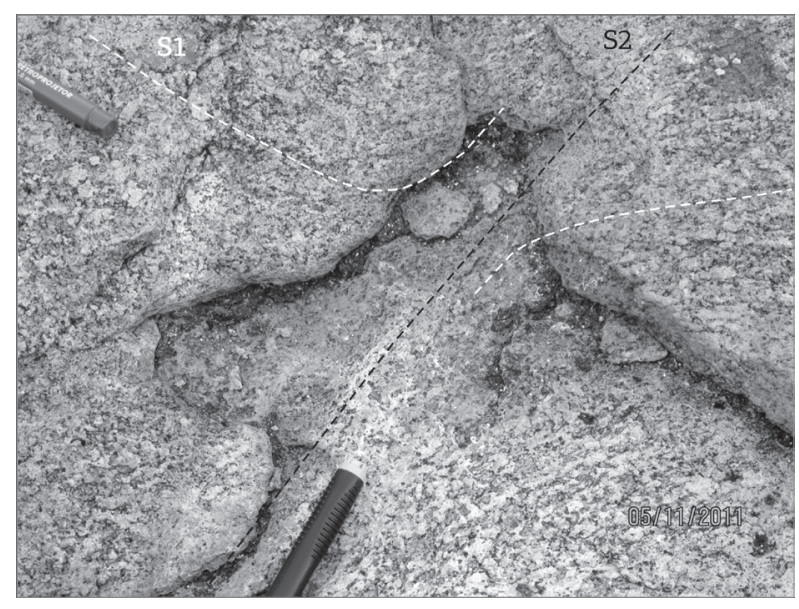

Figure 8. Cross-cutting relationship between the foliation $\left(\mathrm{S}_{1}\right)$ and ductile shear zones $\left(\mathrm{S}_{2}\right)$ that are parallel to the $D_{2}$ folds.

\section{GEOCHEMICAL CHARACTERIZATION}

For the geochemical study of the MG rocks, twelve samples were selected to obtain the chemical composition of the major, minor and trace elements, including the rare earth elements (REE), to determine the geochemical characterization and to identify the nature of magmatism and tectonic setting of these rocks. Initially, the samples were treated in the Laboratory of Sample Preparation of the Department of Mineral Resources (DRM), Federal University of Mato Grosso (Universidade Federal de Mato Grosso - UFMT) and then sent to Acme Analytical Laboratories (Acmelab) in Vancouver, Canada (Table 2) for analysis by the methods Inductively Coupled Plasma (ICP) and Inductively Coupled Plasma Mass Spectrometry (ICP-MS).

The levels of $\mathrm{SiO}_{2}$ in the MG rocks are classified from intermediate to acidic, with concentrations ranging from 59.98 to $62.89 \%$ (hornblende-biotite to tonalite facies) and 65.72 to $68.64 \%$ (biotite granodiorite to monzogranite facies), and with a distinct compositional gap between 62.89 and $65.72 \%$, because of a possible lack of outcrops. The Harker diagrams (Harker 1909; Fig. 9) show trends with negative linear correlations between silica and $\mathrm{TiO}_{2}, \mathrm{MgO},\left(\mathrm{Fe}_{2} \mathrm{O}_{3}\right) t, \mathrm{P}_{2} \mathrm{O}_{5}, \mathrm{CaO}$ and $\mathrm{Sr}$, which reflect the fractionation of calcic plagioclase and primary mafic minerals, such as amphibole, biotite, titanite, Fe/Ti oxides and apatite during the magmatic evolution. Correlations are not observed for the $\mathrm{K}_{2} \mathrm{O}$, $\mathrm{Na}_{2} \mathrm{O}$ and $\mathrm{Al}_{2} \mathrm{O}_{3}$ oxides.

The MG rocks are geochemically classified as tonalites, granodiorites and monzogranites in the R1-R2 chemical variation diagram (La Roche 1980; Fig. 10A), and when the Q-P diagram is used (Debon \& Le Fort 1983; Fig. 10B), they fall within the domains of the quartz-monzonites, monzogranites and granites.

According to the Total Alkali Silica (TAS) diagram (Fig. 11A), the Irvine and Baragar (1971) dividing line suggests that the magmatism that originated the MG rocks is of subalkaline affinity, and its alkali-calcic character is evident from the Peacock diagram (Peacock 1931; Fig. 11B) because of the intersection of the trends of total alkalis and $\mathrm{CaO}$ versus $\mathrm{SiO}_{2}$ obtained for the rocks studied with an alkalinity index of approximately 55 , which is confirmed by the $\mathrm{Na}_{2} \mathrm{O}+\mathrm{K}_{2} \mathrm{O}-\mathrm{CaO}$ versus $\mathrm{SiO}_{2}$ trend proposed by Frost et al. (2001; Fig. 11C). In the $\mathrm{K}_{2} \mathrm{O}$ versus $\mathrm{SiO}_{2}$ diagram, the high $\mathrm{K}$ values classify this magmatism as shoshonitic (Peccerillo \& Taylor 1976; Fig. 11D).

Using alkalinity index (Shand 1927) and the A/CNK versus A/NK diagram proposed by Maniar and Piccoli (1989; Fig. 12A), the samples have been classified as metaluminous except for two from the BGMF, which plot in the peraluminous field. In the diagram proposed by Frost et al. (2001; Fig. 12B), which is based on the $\mathrm{FeOt} /(\mathrm{FeOt}+\mathrm{MgO})$ versus $\mathrm{SiO}_{2}$ relationship and which differentiates between the magnesium and iron granites, the samples are plotted in the iron granite field.

To characterize the tectonic setting, the R1-R2 (Fig. 13A) and $\mathrm{Rb}$ versus $\mathrm{Y}+\mathrm{Nb}$ (Fig. 13B) diagrams, proposed by Batchelor and Bowden (1985), Pearce et al. (1984) and Pearce (1996), respectively, were used. The distributions of the analyzed samples in these diagrams suggest magmatism that is compatible with the granite series generated in lateto post-orogeny environments.

The geochemical pattern obtained for these rocks, which was normalized to Nakamura's chondrite values (Nakamura 1977; Fig. 14A), shows a fractionation of Heavy Rare Earth Elements (HREE) relative to the Light Rare Earth Elements (LREE) and $(\mathrm{La} / \mathrm{Yb}) \mathrm{n}$ ratios between 9.01 and 35.05. Discrete negative Eu anomalies are observed with $\mathrm{Eu} / \mathrm{Eu}^{*}$ ratios ranging from 0.25 to 0.56 , which corroborate the plagioclase fractionation hypothesis suggested by the $\mathrm{CaO}$ versus silica graph (Fig. 9). In the multi-element distribution and $\mathrm{K}_{2} \mathrm{O}$ diagram (Fig. 14B), which were normalized against Ocean Ridge Granite (ORG) values from Pearce et al. (1984), these rocks are characterized by enrichment in large ionic radius lithophile elements (LILE) relative to the high field strength elements (HFSE) and show a pattern similar to that of volcanic arc granitoids (VAG), which were defined by these authors, and $\mathrm{Ta}$ and $\mathrm{Nb}$ negative anomalies, which support this hypothesis. 
Ohana França et al.

Table 2. Chemical composition of the MG samples (oxides in wt\% and other elements in ppm)

\begin{tabular}{|c|c|c|c|c|c|c|c|c|c|c|c|c|}
\hline Elem. & $\begin{array}{l}\text { FC- } \\
16 B\end{array}$ & $\begin{array}{l}\text { FC- } \\
17 B\end{array}$ & $\begin{array}{l}\text { FC- } \\
16 C\end{array}$ & $\begin{array}{l}\text { FC- } \\
19\end{array}$ & $\begin{array}{l}\text { FC- } \\
\text { 22B }\end{array}$ & $\begin{array}{l}\text { FC- } \\
57 A\end{array}$ & $\begin{array}{l}\text { FC- } \\
\text { 57B }\end{array}$ & $\begin{array}{l}\text { OF- } \\
\text { 05B }\end{array}$ & $\begin{array}{l}\text { FC- } \\
57 C\end{array}$ & $\begin{array}{l}\text { OF- } \\
\text { 05A }\end{array}$ & $\begin{array}{l}\text { FC- } \\
25\end{array}$ & $\begin{array}{l}\text { FC- } \\
104\end{array}$ \\
\hline $\mathrm{SiO}_{2}$ & 9.98 & 60.97 & 62.01 & 62.42 & 62.89 & 65.72 & 65.90 & 65.90 & 66.77 & 66.86 & 67.26 & 68.64 \\
\hline $\mathrm{TiO}_{2}$ & 41 & 1.41 & 1.42 & 35 & 1.27 & .88 & 0.83 & 0.80 & 0.78 & 0.77 & 0.64 & 0.47 \\
\hline $\mathrm{Al}_{2} \mathrm{O}_{3}$ & 15.24 & 14.79 & 14.64 & 14.41 & 14.63 & 14.57 & 14.56 & 14.89 & 14.48 & 14.61 & 14.58 & 14.79 \\
\hline $\mathrm{Fe}_{2} \mathrm{O}_{3}$ & 8.10 & 8.04 & 7.47 & 8.04 & 7.24 & 5.11 & 5.44 & 5.09 & 4.64 & 4.85 & 5.01 & 3.84 \\
\hline MnO & 0.11 & 0.12 & 0.11 & 0.12 & 0.10 & 0.07 & 0.07 & 0.06 & 0.06 & 0.06 & 0.06 & 0.04 \\
\hline MgO & 2.17 & 1.93 & 1.86 & 1.78 & 1.72 & 1.34 & 1.38 & 1.23 & 1.25 & 1.17 & 1.07 & 0.79 \\
\hline $\mathrm{CaO}$ & 4.20 & 3.91 & 3.95 & 3.70 & 3.69 & 2.93 & 3.00 & 2.67 & 2.80 & 2.51 & 2.18 & 1.54 \\
\hline $\mathrm{Na}_{2} \mathrm{O}$ & 3.01 & 2.88 & 2.86 & 2.91 & 2.93 & 2.75 & 2.82 & 2.91 & 2.68 & 2.80 & 3.00 & 2.59 \\
\hline $\mathrm{K}_{2} \mathrm{O}$ & 4.16 & 4.19 & 4.00 & 4.08 & 4.14 & 4.99 & 4.56 & 5.08 & 5.15 & 5.16 & 4.99 & 6.37 \\
\hline $\mathrm{P}_{2} \mathrm{O}_{5}$ & 0.64 & 0.61 & 0.59 & 0.58 & 0.54 & 0.33 & 0.34 & 0.31 & 0.29 & 0.31 & 0.28 & 0.20 \\
\hline LOI & 0.50 & 0.70 & 0.60 & 0.20 & 0.40 & 0.90 & 0.70 & 0.70 & 0.70 & 0.50 & 0.60 & 0.40 \\
\hline Total & 99.53 & 99.56 & 99.52 & 99.60 & 99.55 & 99.59 & 99.60 & 99.64 & 99.60 & 99.60 & 99.67 & 99.67 \\
\hline $\mathrm{Ba}$ & 1493.00 & 1325.00 & 1414.00 & 1286.00 & 1332.00 & 1461.00 & 1336.00 & 1410.00 & 1476.00 & 1413.00 & 1306.00 & 963.00 \\
\hline Co & 15.30 & 12.90 & 11.80 & 12.80 & 11.80 & 13.40 & 8.30 & 7.90 & 9.10 & 7.80 & 8.80 & 6.00 \\
\hline Cs & 1.50 & 1.60 & 1.90 & 1.60 & 1.90 & 0.90 & 0.80 & 1.40 & 0.60 & 1.20 & 2.20 & 0.70 \\
\hline $\mathrm{Ga}$ & 22.60 & 19.00 & 18.60 & 20.60 & 21.00 & 18.90 & 18.70 & 17.10 & 18.40 & 17.10 & 20.60 & 17.90 \\
\hline Hf & 19.00 & 20.50 & 19.70 & 17.80 & 19.20 & 17.10 & 16.20 & 16.10 & 14.20 & 15.30 & 11.60 & 11.20 \\
\hline $\mathrm{Nb}$ & 28.90 & 29.60 & 30.10 & 33.00 & 32.10 & 20.10 & 17.20 & 17.60 & 18.90 & 16.20 & 21.50 & 16.80 \\
\hline $\mathbf{R b}$ & 197.90 & 168.60 & 174.50 & 189.80 & 201.10 & 213.30 & 202.50 & 224.30 & 207.30 & 229.80 & 255.30 & 266.90 \\
\hline $\mathrm{Sr}$ & 366.50 & 330.80 & 351.20 & 337.40 & 316.20 & 293.50 & 295.70 & 298.60 & 291.90 & 290.30 & 270.40 & 201.90 \\
\hline $\mathrm{Ta}$ & 10 & 20 & 40 & 1.70 & 1.70 & 00 & 00 & 0 & 1.00 & .50 & 1.20 & 0.70 \\
\hline Th & 21.40 & 27.00 & 25.50 & 21.80 & 38.80 & 36.90 & 38.50 & 24.20 & 42.60 & 29.90 & 64.40 & 135.20 \\
\hline $\mathrm{U}$ & 2.30 & 1.80 & 2.10 & 2.50 & 3.40 & 1.90 & 1.70 & 1.40 & 1.60 & 1.30 & 3.80 & 2.50 \\
\hline w & $<0.50$ & 0.60 & $<0.50$ & 1.00 & 1.10 & $<0.50$ & $<0.50$ & $<0.50$ & $<0.50$ & 0.60 & $<0.50$ & $<0.50$ \\
\hline $\mathrm{Zr}$ & 744.10 & 792.60 & 772.90 & 694.40 & 782.50 & 649.30 & 636.20 & 574.10 & 567.50 & 556.40 & 406.50 & 384.90 \\
\hline $\mathbf{Y}$ & 68.80 & 66.30 & 75.30 & 70.00 & 70.30 & 55.30 & 41.40 & 37.40 & 53.30 & 26.10 & 37.30 & 40.80 \\
\hline La & 1.60 & 142.50 & 140.20 & 89.10 & 141.20 & 115.70 & 91.90 & 84.80 & 136.50 & 92.80 & 94.10 & 134.60 \\
\hline $\mathrm{Ce}$ & 245.70 & 282.70 & 314.80 & 226.10 & 307.60 & 265.40 & 218.80 & 186.70 & 306.50 & 196.10 & 210.10 & 331.80 \\
\hline $\mathrm{Pr}$ & 30.71 & 34.19 & 37.52 & 27.88 & 36.68 & 32.70 & 27.54 & 23.71 & 36.69 & 24.08 & 22.97 & 38.65 \\
\hline Nd & 122.60 & 125.30 & 143.50 & 112.20 & 139.40 & 130.10 & 111.60 & 91.40 & 143.60 & 85.70 & 82.50 & 150.40 \\
\hline $\mathrm{Sm}$ & .59 & 21.93 & 24.80 & 20.80 & 22.62 & 20.94 & 17.55 & 16.87 & 22.18 & 13.19 & 13.19 & 25.43 \\
\hline $\mathbf{E u}$ & 3.46 & 2.93 & 3.59 & 3.02 & 3.17 & 2.53 & 2.10 & 2.38 & 2.68 & 1.99 & 1.24 & 1.70 \\
\hline Gd & 16.85 & 17.75 & 20.00 & 16.68 & 17.50 & 14.68 & 11.81 & 12.93 & 15.76 & 9.94 & 8.86 & 17.24 \\
\hline Tb & 2.45 & 2.35 & 2.77 & 2.53 & 2.45 & 2.08 & 1.62 & 1.61 & 2.12 & 1.21 & 1.26 & 2.11 \\
\hline Dy & 14.12 & 12.58 & 15.21 & 12.49 & 13.58 & 10.31 & 8.26 & 8.15 & 10.89 & 5.77 & 6.15 & 8.74 \\
\hline Ho & 2.37 & 2.41 & 2.81 & 2.70 & 2.50 & 1.90 & 1.36 & 1.43 & 1.81 & 0.90 & 1.36 & 1.57 \\
\hline Er & 6.72 & 6.44 & 7.30 & 7.27 & 7.43 & 34 & 3.90 & 3.49 & 5.08 & 2.13 & 3.58 & 3.91 \\
\hline $\mathrm{Tm}$ & 1.00 & 0.95 & 1.07 & 1.13 & 1.06 & 0.72 & 0.57 & 0.47 & 0.77 & 0.34 & 0.41 & 0.50 \\
\hline $\mathrm{Yb}$ & 6.17 & 5.97 & 6.86 & 6.59 & 6.79 & 4.63 & 3.55 & 2.54 & 4.51 & 2.04 & 2.17 & 2.56 \\
\hline $\mathbf{L u}$ & 0.87 & 0.89 & 1.00 & 1.00 & 1.00 & 0.67 & 0.52 & 0.43 & 0.63 & 0.31 & 0.35 & 0.43 \\
\hline $\mathbf{E u} / \mathbf{E u}^{*}$ & 0.56 & 0.46 & 0.50 & 0.50 & 0.49 & 0.44 & 0.45 & 0.50 & 0.44 & 0.53 & 0.35 & 0.25 \\
\hline$(\mathrm{La} / \mathrm{Yb}) \mathrm{N}$ & 12.06 & 15.91 & 13.62 & 9.01 & 13.86 & 16.66 & 17.26 & 22.26 & 20.18 & 30.33 & 28.91 & 35.05 \\
\hline
\end{tabular}




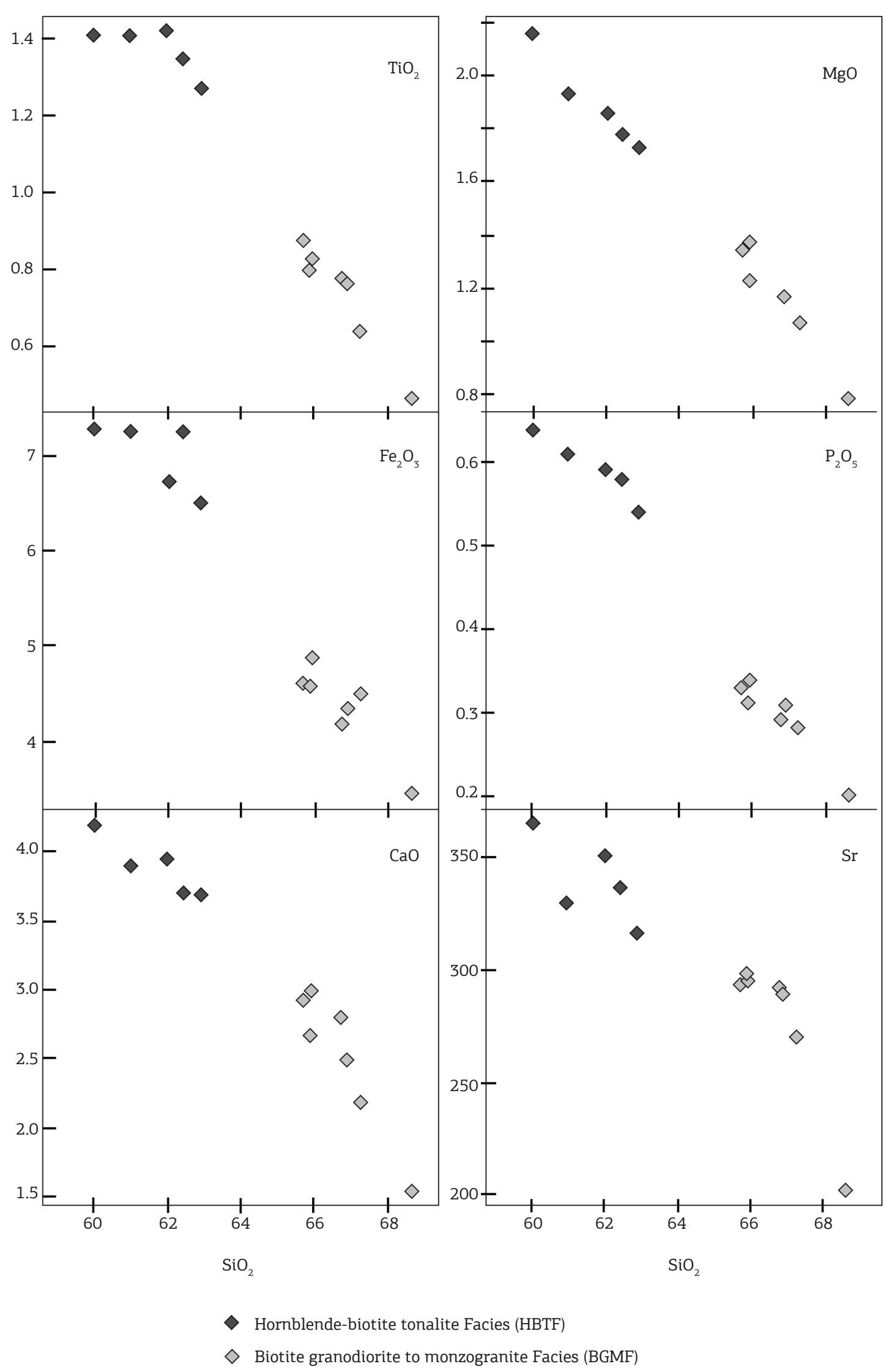

Figure 9. Harker diagrams: variation of $\mathrm{SiO}_{2}$ versus oxides (wt\%) and minor and major elements (ppm) of the $\mathrm{MG}$ rocks. 


\section{A}

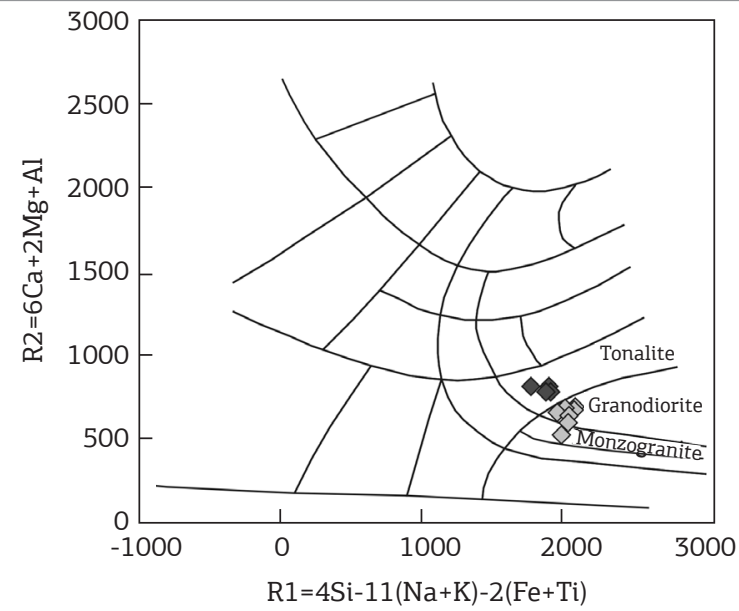

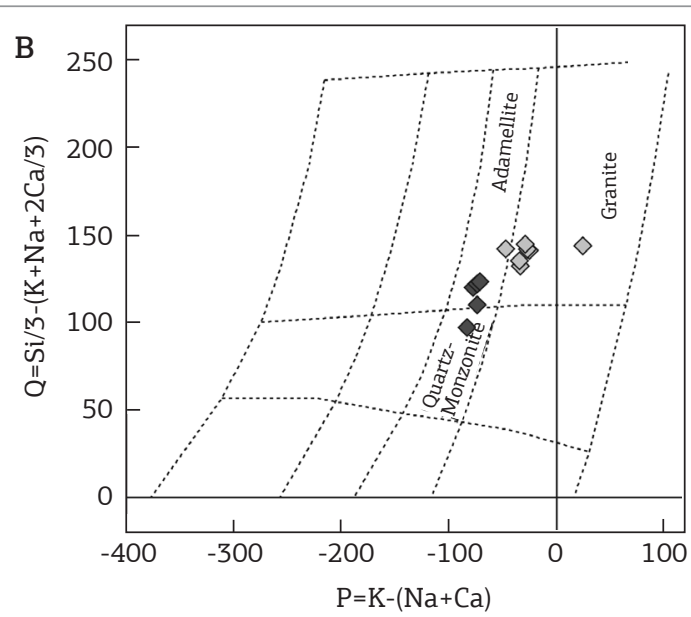

- Hornblende-biotite tonalite Facies (HBTF)

$\diamond$ Biotite granodiorite to monzogranite Facies (BGMF)

Figure 10. Geochemical classification diagrams for the MG rocks: (A) R1 versus R2 (La Roche 1980). (B) Q-P (Debon \& Le Fort 1983).

A

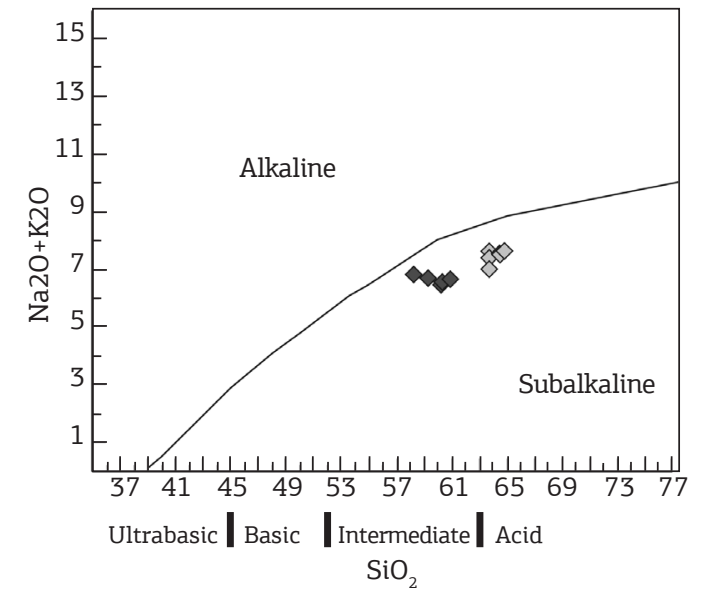

C

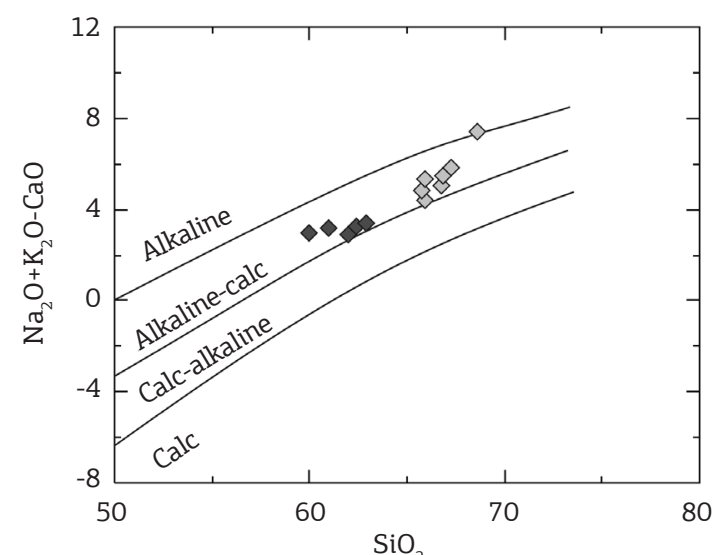

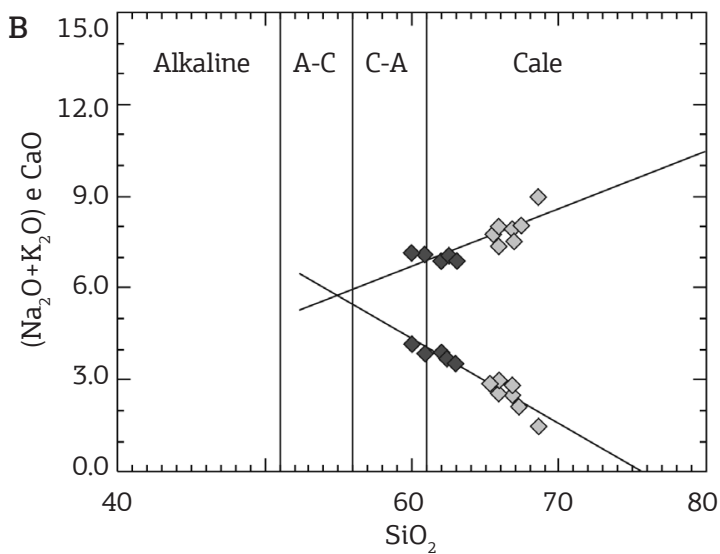

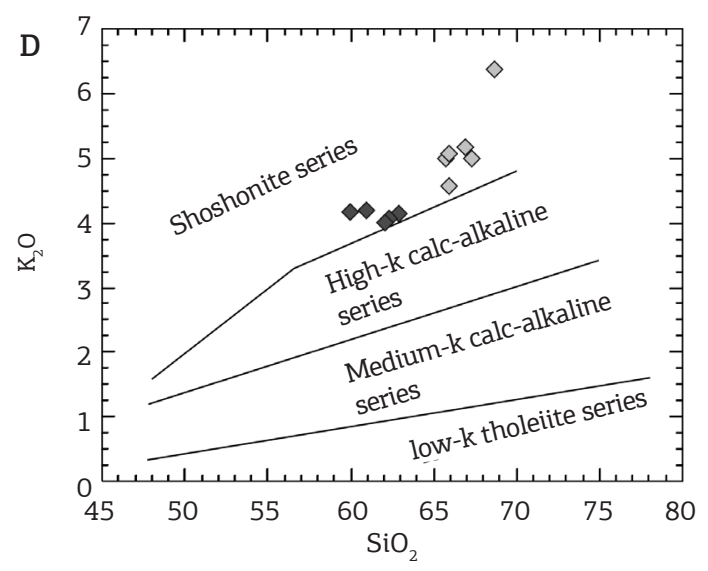

Hornblende-biotite tonalite Facies (HBTF)

$\diamond$ Biotite granodiorite to monzogranite Facies (BGMF)

Figure 11. Classification diagrams of the magmatic series for the MG rocks: (A) total alkalis versus silica (Irvine \& Baragar 1971). (B) total alkalis and $\mathrm{CaO}$ versus silica (Peacock 1931). (C) $\mathrm{Na}_{2} \mathrm{O}+\mathrm{K}_{2} \mathrm{O}-\mathrm{CaO}$ versus $\mathrm{SiO}_{2}$ (Frost et al. 2001); (D) $\mathrm{K}_{2} \mathrm{O}$ versus $\mathrm{SiO}_{2}$ (Peccerillo \& Taylor 1976). 
A

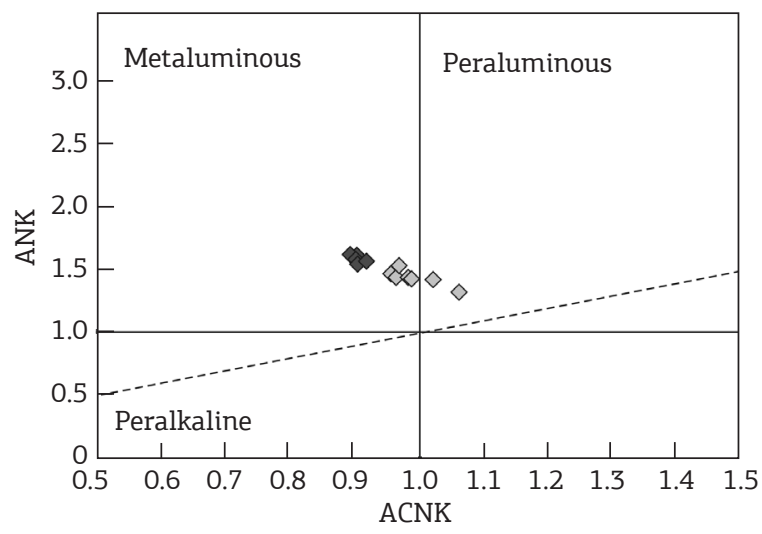

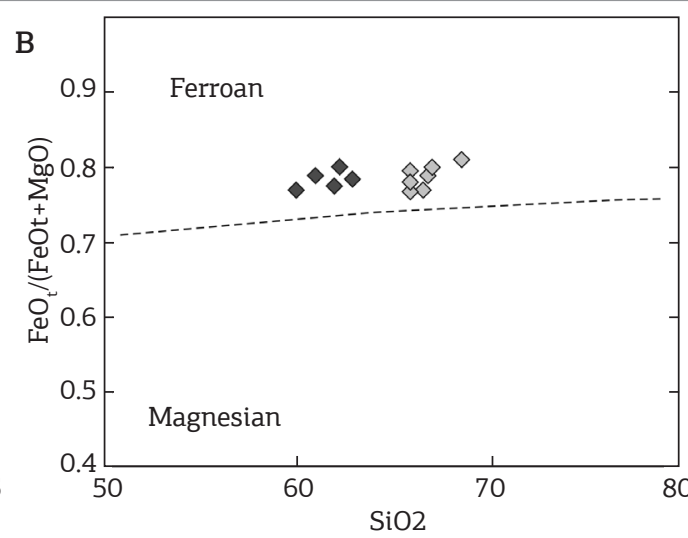

- Hornblende-biotite tonalite Facies (HBTF)

$\diamond$ Biotite granodiorite to monzogranite Facies (BGMF)

Figure 12. Diagrams (A) A/CNK versus A/NK (Maniar \& Piccoli 1989). (B) FeOt/(FeOt+MgO) versus $\mathrm{SiO}_{2}$ (Frost et al. 2001).

A

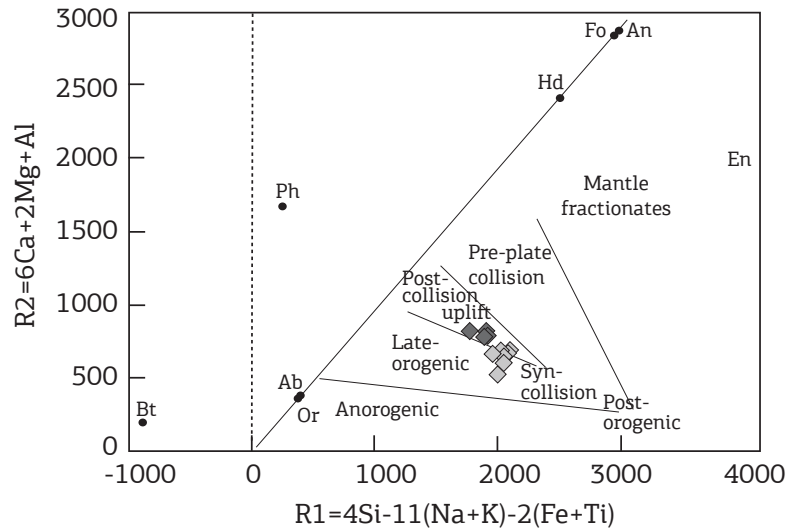

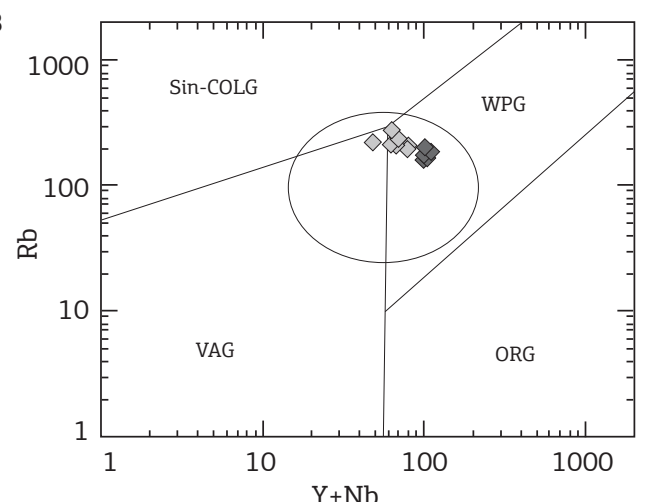

$\checkmark$ Hornblende-biotite tonalite Facies (HBTF)

$\diamond$ Biotite granodiorite to monzogranite Facies (BGMF)

Figure 13. Distribution of points representative of the MG rocks in the following diagrams: (A) R1-R2 (Batchelor \& Bowden 1985). (B) Rb versus $\mathrm{Y}+\mathrm{Nb}$ (Pearce et al. 1984; Pearce 1996).

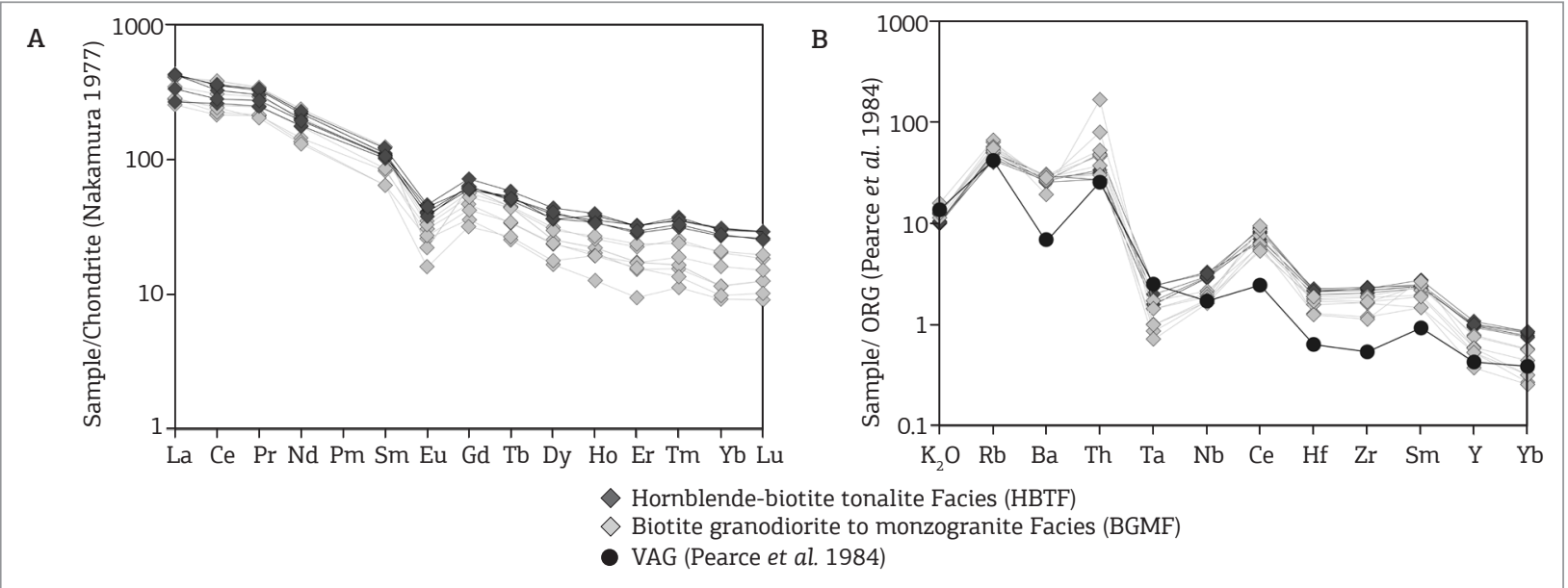

Figure 14. Distribution patterns of the MG rocks in the following diagrams: (A) Rare Earth Elements; ETR normalized to Nakamura's chondrite values (Nakamura, 1977). (B) trace elements and $\mathrm{K}_{2} \mathrm{O}$ normalized to the ocean ridge granite values (Pearce et al. 1984). 


\section{GEOCHRONOLOGICAL (U-PB SHRIMP) AND ISOTOPIC (SM-ND) ANALYSES}

To identify the crystallization age and magma source that generated the MG, the samples FC-22B (UTM coordinates 174564/8226783) and FC-41A (UTM coordinates $187513 / 8214239$ ) were collected near the farms Nossa Senhora das Graças and Fortaleza, respectively, and subjected to geochronological and isotopic analyses. The FC-22B sample corresponds to the HBTF, and it was analyzed by the U-Pb (SHRIMP) zircon technique. The FC-41A sample is related to the BGMF, and it was subjected to a $\mathrm{Sm}-\mathrm{Nd}$ isotopic analysis.

The samples were processed in the Laboratory of Sample Preparation of the Minerals Resources Department (Departamento de Recursos Minerais-DRM), UFMT. The U-Pb (SHRIMP) zircon isotopic data were obtained in the laboratory of the Center for Geochronological Research of the Institute of Geosciences, University of São Paulo (Centro de Pesquisas Geocronológicas do Instituto de Geociências da Universidade de São Paulo - CPGeoIGc - USP), whereas the total rock Sm-Nd analyses were conducted in the Laboratory of Isotopic Geology, Federal University of Pará (Laboratório de Geologia Isotópica da Universidade Federal do Pará - Pará-Iso - UFPA).

\section{$\mathrm{U}-\mathrm{Pb}$ (SHRIMP) Zircon Analysis}

Sample FC-22B was prepared following the conventional procedures, including crushing, grinding and sieving into fractions between 63 and 250 mesh. The 90 mesh fraction was used in the analyses, and 100 zircon crystals were selected and sent to the CPGeo-IGc/USP laboratory to obtain images of the crystals by cathodoluminescence in the scanning electron microscope (SEM).

The U-Pb zircon isotopic data were obtained by secondary ion mass spectrometry (SIMS) with the SHRIMP IIe microprobe
(Sensitive High Resolution Ion Microprobe). Details of the analytical procedures and calibration of the device are described by Stern (1998), Williams (1998) and Sato et al. (2008). The U content was calibrated against the standard crystal SL13 with 238 ppm of $\mathrm{U}(< \pm 10 \%)$, whereas the $\mathrm{Pb} / \mathrm{U}$ ratio was calibrated against the AS57 standard with an age of $1100 \mathrm{Ma}$ (Paces \& Miller 1993).

The decay constants and present-day ${ }^{238} \mathrm{U} / 235 \mathrm{U}$ ratio used in the calculations were those provided by Steiger and Jäger (1977). The integrated age calculation was performed with the weighted averages of the points corresponding to the same zircon generation based on the cathodoluminescence image interpretation. The ages were calculated with the Ludwig software Isoplot/EX (Ludwig 1998).

Ten zircon crystals were selected for imaging by SEM and subsequent geochronological analyses. The zircon crystals were elongated with well-developed prisms, which had lengths between 150 and $200 \mu \mathrm{m}$, with a length versus width ratio equal to $2 / 1$; however, a minor portion of the crystals presented this ratio as $4 / 1$. The crystals appeared in light yellow and bronze colors, ranging from translucent to opaque, and some were fractured and broken.

In the cathodoluminescence images (Fig. 15), the crystals FC-22B 1.1, FC-22B 2.1, FC-22B 3.1, FC-22B 4.1, FC-22B 5.1, FC-22B 6.1, FC-22B 7.1, FC-22B 9.1, FC-22B 10.1 and FC-22B 11.1 exhibited magmatic zoning with relatively regular alternating light and dark bands. Inherited cores were not observed. Crystal FC-22B 1.1 was homogeneous with no internal zoning; crystals FC-22B 2.1, FC-22B 5.1, FC-22B 7.1 and FC-22B 10.1 showed more than one growth phase with an emphasis on homogeneous overgrowth.

The results of the $\mathrm{U} / \mathrm{Pb}$ analyses are shown in Table 3. The ${ }^{206} \mathrm{~Pb} /{ }^{238} \mathrm{U}$ ages range between $1,324 \pm 64$ and $1,375 \pm 55 \mathrm{Ma}$. In the Concordia diagram (Fig. 16), the analytical points provided a concordant age of $1,350 \pm 12 \mathrm{Ma}$. The result was interpreted as the crystallization age of the MG.

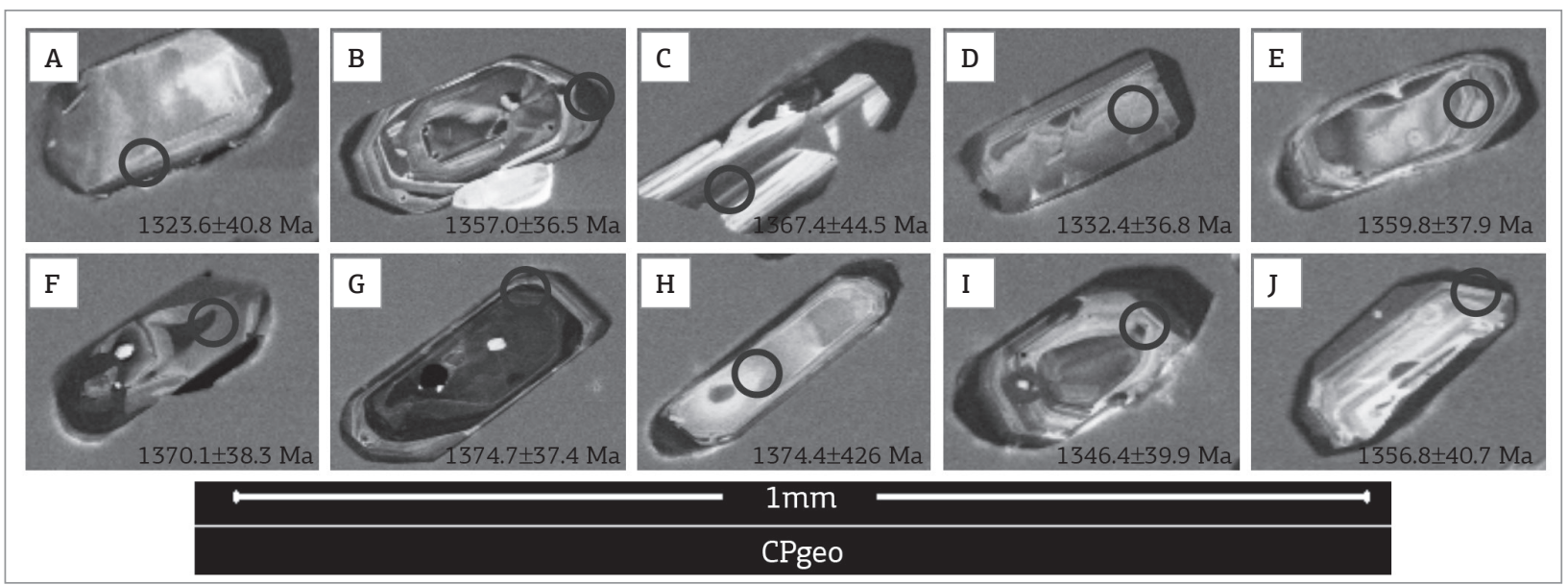

Figure 15. Cathodoluminescence image of the zircon crystals (A) FC-22B 1.1. (B) FC-22B 2.1. (C) FC-22B 3.1. (D) FC-22B 4.1. (E) FC-22B 5.1. (F) FC-22B 6.1. (G) FC-22B 7.1. (H) FC-22B 9.1. (I) FC-22B 10.1. (J) FC-22B 11.1. The image also indicates the points of impact of the ion beam. 
Table 3. Isotopic data of the zircons for MG from the sample FC-22B

\begin{tabular}{|c|c|c|c|c|c|c|c|c|c|c|c|c|c|c|c|c|c|}
\hline Sample & $\begin{array}{c}\mathrm{U} \\
(\mathrm{ppm})\end{array}$ & $\begin{array}{c}\text { Th } \\
\text { (ppm) }\end{array}$ & $\begin{array}{c}{ }^{232} \mathrm{Th} / \\
{ }^{238} \mathrm{U}\end{array}$ & $\begin{array}{c}{ }^{206} \mathrm{~Pb}_{\mathrm{c}} \\
\%\end{array}$ & $\begin{array}{c}{ }^{206} \mathrm{~Pb}^{*} \\
\mathrm{ppm}\end{array}$ & $\begin{array}{l}{ }^{207} \mathrm{~Pb} / \\
{ }^{235} \mathrm{U} \\
(1)\end{array}$ & $\pm \%$ & $\begin{array}{c}{ }^{206} \mathrm{~Pb} / \\
{ }^{238} \mathrm{U} \\
(1)\end{array}$ & $\pm \%$ & $\begin{array}{c}{ }^{207} \mathrm{~Pb} / \\
{ }^{206} \mathrm{~Pb} \\
(1)\end{array}$ & $\pm \%$ & $\begin{array}{c}{ }^{206} \mathrm{~Pb} /{ }^{238} \mathrm{U} \\
\text { Age(Ma) } \\
\text { (1) }\end{array}$ & $\pm 1 \mathrm{~s}$ & $\begin{array}{c}{ }^{207} \mathrm{~Pb} /{ }^{206} \mathrm{~Pb} \\
\text { Age (Ma) } \\
\text { (1) }\end{array}$ & $\pm 1 \mathrm{~s}$ & $\begin{array}{c}\text { disc } \\
\%\end{array}$ & $\begin{array}{l}\text { Err. } \\
\text { Corr. }\end{array}$ \\
\hline L.1 & 69 & I0 & 2.11 & 3.00 & 13.9 & 2.59 & 10.9 & 0.2279 & 3.4 & 0.0823 & 10.1 & 1323.6 & 40.8 & 1252 & 202 & -5 & שN" \\
\hline FC22B-2.1 & 316 & 126 & 0.41 & 0.78 & 64.1 & 2.65 & 5.5 & 0.2343 & 3.0 & 0.0819 & 4.5 & 1357.0 & 36.5 & 1243 & 90 & -8 & .547 \\
\hline FC22B-3.1 & 85 & 178 & 2.17 & 1.08 & 17.4 & 2.94 & 6.4 & 0.2363 & 3.6 & 0.0902 & 5.2 & 1367.4 & 44.5 & 1431 & 100 & 5 & 0.566 \\
\hline FC22B-4.1 & 245 & 154 & 0.65 & 1.28 & 49.0 & 2.55 & 7.5 & 0.2296 & 3.1 & 0.0806 & 6.8 & 1332.4 & 36.8 & 1212 & 134 & -9 & 0.410 \\
\hline FC22B-5.1 & 186 & 162 & 0.90 & 2.41 & 38.6 & 2.68 & 7.4 & 0.2348 & 3.1 & 0.0828 & 6.5 & 359.8 & 37.9 & 263 & 130 & -7 & 0.421 \\
\hline FC22B-6.1 & 180 & 259 & 1.49 & 1.25 & 37.1 & 2.66 & 6.0 & 0.2368 & 3.1 & 0.0815 & 5.1 & 1370.1 & 38.3 & 1233 & 101 & -10 & 0.516 \\
\hline FC22B-7.1 & 385 & 197 & 0.53 & 0.59 & 79.1 & 2.80 & 4.1 & 0.2377 & 3.0 & 0.0854 & 2.8 & 1374.7 & 37.4 & 1325 & 54 & -4 & 0.734 \\
\hline FC22B-9.1 & 70 & 73 & 1.08 & 1.91 & 14.6 & 2.77 & 11.8 & 0.2376 & 3.5 & 0.0846 & 11.2 & 1374.4 & 42.6 & 1306 & 219 & -5 & 0.295 \\
\hline FC22B-10.1 & 85 & , & & 1.87 & 17.4 & 2.70 & 8.2 & 0.2323 & 3.3 & 0.0842 & 7.4 & 6.4 & 39.9 & 12 & 145 & -4 & 0.403 \\
\hline FC22B-11.1 & 76 & 102 & 1.39 & 2.21 & 15.7 & 2.66 & 8.8 & 0.2341 & 3.3 & 0.0824 & 8.0 & 1356.0 & 40.7 & 1255 & 160 & -7 & 0.378 \\
\hline
\end{tabular}

Common lead-corrected ratio. 1-sigma error.

\section{Sm-Nd Isotopic Analysis}

The analytical procedure adopted at the Pará-Iso laboratory for the $\mathrm{Sm}-\mathrm{Nd}$ total rock methodology is described in Barreto et al. (2014). The sample FC-41A was previously powdered and dissolved with $\mathrm{HNO}_{3}, \mathrm{HCl}$ and $\mathrm{HF}$ in a microwave oven after the introduction of a mixed ${ }^{149} \mathrm{Sm} /{ }^{150} \mathrm{Nd}$ tracer to determine the contents of $\mathrm{Sm}$ and $\mathrm{Nd}$ by isotope dilution. Chemical separation by chromatography was conducted on an ion exchange resin in two steps: the first step separated the REE group from the other elements using a Teflon column with a cation exchange resin, and the second step separated the Sm and Nd elements from each other and from the other REEs in a Teflon column with Eichron ${ }^{\circ} \mathrm{Ln}$-Spec resin. After collection and drying, the Sm and $\mathrm{Nd}$ concentrated fractions were solubilized with $\mathrm{HNO}_{3}$.

The ${ }^{143} \mathrm{Nd} /{ }^{144} \mathrm{Nd}$ ratios were normalized against the value ${ }^{146} \mathrm{Nd} /{ }^{144} \mathrm{Nd}=0.7219$. The reproducibility of the isotopic results was evaluated by repeated La Jolla standard analyses. The decay constant was $6.54 \times 10^{-12} /$ year $^{-1}$ (Lugmair \& Marti, 1978), and the calculations of the model ages were based on the depleted-mantle evolution model of DePaolo (1981).

The Sm-Nd isotopic data for the MG sample (Table 4) determined a $\mathrm{T}_{\mathrm{DM}}$ model age of $1.77 \mathrm{Ga}$ and an $\varepsilon_{\mathrm{Nd}(1.35)}$ value of -2.57 based on an age of $1,350 \pm 12 \mathrm{Ma}$ for the crystallization of the granitic magma.

The negative value of $\mathcal{E}_{\mathrm{Nd}(1.35)}$ and $\mathrm{T}_{\mathrm{DM}}$ model age of 1.77 Ga suggest a crustal source for the MG that involved partial melting processes of a Paleoproterozoic (Statherian) continental crust during its generation.

\section{CONCLUSIONS}

The MG corresponds to a slightly elongated batholith in the NNW direction, partially covered by unconsolidated quaternary sediments from the Guaporé Formation, and it is composed by two petrographic facies: HBTF and BGMF.

Tectonic structures of ductile and ductile-ruptile nature indicate that the MG underwent two deformational

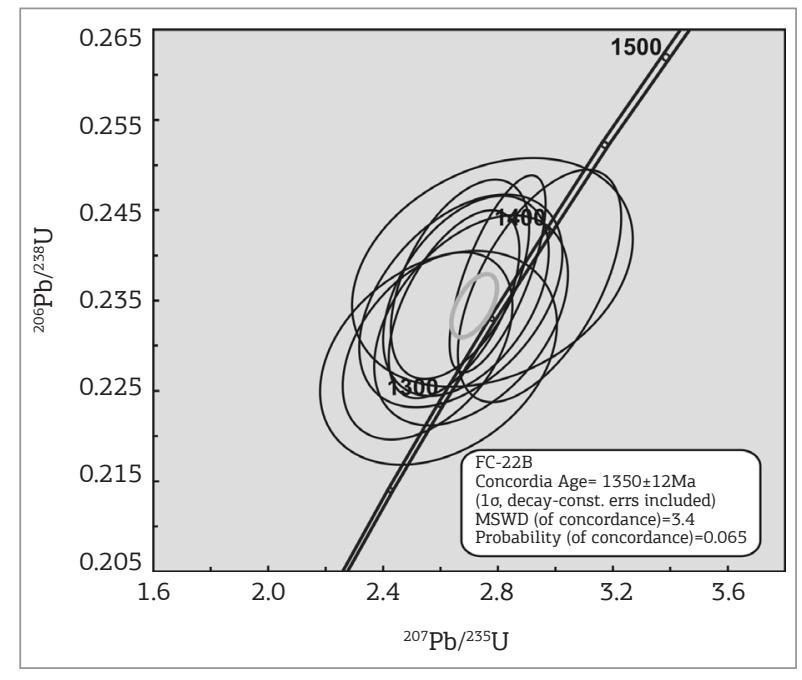

Figure 16. Concordia diagram of U/Pb (SHRIMP) zircon isotopic age from sample FC-22B of MG.

Table 4. Sm-Nd isotopic analytical data of the MG

\begin{tabular}{l|c|c|c|c|c|c|c|c}
\hline Sample & $\mathbf{S m}$ & $\mathbf{N d}$ & $\begin{array}{c}{ }^{147} \mathbf{S m} / \\
{ }^{144} \mathbf{N d}\end{array}$ & $\begin{array}{c}{ }^{143} \mathbf{N d} / \\
{ }^{144} \mathbf{N d}\end{array}$ & $\begin{array}{c}\mathbf{f} \\
(\mathbf{S m} / \mathbf{N d})^{*}\end{array}$ & $\varepsilon \mathbf{N d}_{(0)}$ & $\mathbf{T}_{(\mathrm{DM})}$ & $\varepsilon \mathbf{E d}_{(1,35)}$ \\
\hline FC-41A & 5.43 & 45.46 & 0.072264 & 0.511403 & -0.6326 & -24.09 & 1.77 & -2.57 \\
\hline
\end{tabular}

* $\mathrm{f}(\mathrm{Sm} / \mathrm{Nd}): \mathrm{Sm} / \mathrm{Nd}$ fractionation factor relative to chondritic meteorites (DePaolo 1988).

phases $\left(F_{1}\right.$ and $\left.F_{2}\right)$ responsible for the formation of discrete penetrative foliation $\left(\mathrm{S}_{1}\right)$ in a N30W/80SW preferential direction with narrow shear zones parallel to the axial plane of the folds $\left(\mathrm{D}_{2}\right)$ that have a dominant attitude of N80E/85NW. The $S_{1}$ foliation exhibits paragenesis, which indicates conditions of regional metamorphism of greenschist facies, whereas the structures generated in $\mathrm{F}_{2}$ are compatible with a shallower crustal level and ruptile-ductile behavior. The $\mathrm{F}_{1}$ phase is tentatively correlated with the main crustal shortening associated with the San Ignácio Orogeny (1.40 to $1.28 \mathrm{Ga}$ ), whereas the $\mathrm{F}_{2}$ phase should be a reflection of the basement deformations related to the evolution of the Aguapeí Belt (Sunsás Orogeny, 1.0 to $0.9 \mathrm{Ga}$ ). 
The studied rocks are an intermediate to acidic sequence formed by a subalkaline magmatism, and they are alkali-calcic, metaluminous to slightly peraluminous, and evolved through fractional crystallization mechanisms. The geochronological U-Pb (SHRIMP) zircon result of 1,350 \pm $12 \mathrm{Ma}$ is interpreted as the crystallization age of the MG. The $\mathrm{Sm}-\mathrm{Nd}$ isotopic data indicate a $\mathrm{T}_{\mathrm{DM}}$ model age of 1.77 $\mathrm{Ga}$, which suggests mantle extraction during the Statherian period, whereas the $\varepsilon \mathrm{Nd}_{(1.35)}$ value of -2.57 suggests a mixed source for these rocks involving partial melting processes of the continental crust during its generation. The $T_{\mathrm{DM}}$ model age is similar to the results obtained for the late- to post-kinematic granitoids of the PIS.

The petrogenetic, deformational and metamorphic MG data suggest that the investigated intrusion was generated in a convergent tectonic environment with a continental magmatic arc in late- to post-orogenic stages of the San Ignácio Orogeny (1.40 to $1.28 \mathrm{Ga})$. It is correlated to the Piso Firme, Diamantina, Orabayaya, San Cristobal, Porvenir and Padre Eterno granites (Pensamiento Granitoid Complex), in Bolivia, and Passagem and Lajes granites (PIS), in Brazil. It is accepted that the granitoids from these two granitic units were generated in an accretionary orogen and resulted from the consumption of oceanic lithosphere (Rio
Alegre Terrane) under the PT, which was followed by the continental collision between the two Paleo-Mesoproterozoic terranes Jauru and Paraguá.

\section{ACKNOWLEDGMENTS}

The authors would like to thank the National Council for Scientific and Technological Development (Conselho Nacional de Desenvolvimento Cientifico e Tecnológico - CNPq) (Process number 479779/2011-2), the National Program for Academic Cooperation/Brazilian Federal Agency for the Support and Evaluation of Graduate Education (Programa Nacional de Cooperação Acadêmica/Coordenação de Aperfeiçoamento de Pessoal de Nivel Superior - PROCAD/CAPES) (096/2007), the National Institute of Geosciences and Technology of the Amazon (Instituto Nacional e Tecnologia de Geociências da Amazônia - GEOCIAM) and the Graduate Program in Geosciences, UFMT, for the financial support that allowed the development of this research. The first author thanks the Brazilian Federal Agency for the Support and Evaluation of Graduate Education (Coordenação de Aperfeiçoamento de Pessoal de Nivel Superior - CAPES) for granting her master's scholarship.

\section{REFERENCES}

Barreto C.J.S., Lafon J.M., Costa L.T.R., Lima E.F. 2014. Paleoproterozoic ( 1.89 Ga) felsic volcanism of the Iricoumé Group, Guyana Shield, South America: geochemical and Sm-Nd isotopic constraints on sources and tectonic environment. International Geology Review, 56(11):1332-1356.

Batchelor, R.A. \& Bowden, P. 1985. Petrogenesis interpretation of granitoid rock series using multicationic parameters. Chemical Geology, 48:43-55.

Bettencourt J.S., Leite Jr. W.B., Ruiz A.S., Matos R., Payolla B.L., Tosdal R.M. 2010. The Rondonian-San Ignácio Province in the SW Amazonian Craton: an overview. Journal of South American Earth Sciences, 29(1):28-46.

Boger S.D., Raetz M., Giles D., Etchart E., Fanning C.M. 2005. U-Pb age data from the Sunsas region of Eastern Bolivia: evidence for the allochthonous origin of the Paragua Block. Precambrian Research, 139:121-146.

Debon F. \& Le Fort P. 1983. A chemical-mineralogical classification of common plutonic rocks and associations. Transactions of the Royal Society of Edinburgh, Earth Sciences, 73:135-149.

DePaolo D.J. 1981. Nd isotopic studies: Some New Perspectives on Earth Structure and Evolution. EOS, 62(14):137-145.

DePaolo D.J. 1988. Neodimium Isotope Geochemistry - An Introduction. Springer-Verlag. 490p.

França O., Corrêa A.D.P., Ruiz A.S., Sousa M.Z.A., Batata M.E. 2013. Análise Estrutural Preliminar da Região da Vila Ponta do Aterro (MT) - Terreno Paraguá - SW do Cráton Amazônico [Preliminary
Structural Analysis of the Vila Ponta do Aterro region (MT) Paraguá Terrane - SW Amazonian Craton]. In: Simpósio Nacional de Estudos Tectônicos, Cuiabá, 2013. Anais do XIV Simpósio Nacional de Estudos Tectônicos.

Frost B.R., Barnes C.G, Collins W.J., Arculus R.J., Ellis D.J., Frost C. 2001. A geochemical classification for granitic rocks. Journal of Petrology, 42:2033-2048.

Geraldes M.C. 2000. Geocronologia e geoquímica do plutonismo mesoproterozóico do SW do Estado de Mato Grosso (SW do Cráton Amazônico) [Geochronology and geochemistry of the Mesoproterozoic plutonism in the SW of the state of Mato Grosso (SW Amazonian (raton)]. Doctorate Thesis, Instituto de Geociências, Universidade de São Paulo, São Paulo, 193 p.

Harker A. 1909. The natural history of the igneous rocks. New York, $384 \mathrm{p}$.

Irvine I.N. \& Baragar W.R.A. 1971. A guide to the chemical classification of the common volcanic rocks. Canadian Journal Earth Science, 8:523-548.

Jesus G.C., Sousa M.Z.A., Ruiz A.S., Matos J.B. 2010. Petrologia e geocronologia (U/Pb-Sm/Nd) do Granito Passagem, Complexo Granitóide Pensamiento, SW do Cráton Amazônico (MT) [Petrology and geochronology $(\mathrm{U} / \mathrm{Pb}-\mathrm{Sm} / \mathrm{Nd})$ of the Passagem Granite, Pensamiento Granitoid Complex, SW Amazonian Craton (MT)]. Revista Brasileira de Geociências, 40(3):392-408.

La Roche H. 1980. Granites chemistry through multicationic diagrams. Sciences de la Terre, Série Informatique Géologique, 13:65-88. 
Litherland M., Annells R.N., Appleton J.D., Berrangé J.P., Bloomfield K. Burton C.C.J., Darbyshire D.P.F., Fletcher C.J.N., Hawkins M.P., Klinck B.A., Lanos A., Mithcell W.I., O Connor E.A., Pitfield P.E.J., Power G., Webb B.C. 1986. The Geology and Mineral Resources of the Bolivian Precambrian Shield. London, Her Majesty's Stationery Office, 140 p.

Lugmair G.W, Marti K. 1978. Lunar initial 143Nd/144Nd: differential evolution of the lunar crust and mantle. Earth and Planetary Science Letters. 39:349-357.

Ludwig K.R. 1998. Isoplot/Ex. (v. 1.00b): a geochronological toolkit for Microsoft Excel. Berkeley, Geochronology Center. (Special Publication 1). 45 p.

Maniar P.D. \& Piccoli P.M. 1989. Tectonic discrimination of granitoids. Geological Society of America Bulletin, 101:635-643.

Matos R., Teixeira W., Geraldes M.C., BettencourtJ.S. 2009. Geochemistry and Nd-Sr Isotopic Signatures of the Pensamiento Granitoid Complex, Rondonian-San Ignacio Province, East Precambrian Shield of Bolívia: Petrogenetic Constraints for a Mesoproterozoic Magmatic Arc Setting. Geologia USP Série Científica, 9(2):89-117.

Nakamura K. 1977. Volcanoes as a possible indicator of tectonic stress orientation: principle and proposal. Journal of Volcanology Geothermal Research, 2:1-16.

Nalon P.A., Sousa M.Z.A., Ruiz A.S., Macambira M.J.B. 2013. Batólito Guaporeí: uma extensão do Complexo Granitóide Pensamiento em Mato Grosso, SW do Cráton Amazônico [Guaporeí Batholith: an extension of the Pensamiento Granitoid Complex in Mato Grosso, SW Amazonian Craton]. Brazilian Journal of Geology, 43(1):85-100.

Paces J.B., Miller Jr. J.D. 1993. Precise U-Pb ages of the Duluth Complex and related mafic intrusions, northeastern Minnesota: Geochronological insights to the physical, petrogenetic, paleomagnetic, and tectonomagmatic processes associated with the $1.1 \mathrm{Ga}$ midcontinent rift system. Journal Geophysical Research, 98:13997-14013.

Peacock M.A. 1931. Classification of igneous rock series. Journal of Geology, 39:54-67.

Pearce J.A., Harris N.B.W., Tindle A.G. 1984. Trace element discrimination diagrams for the tectonic interpretation of granitic rocks. Journal of Petrology, 25(4):956-983.

Pearce J.A. 1996. Sources and settings of granitic rocks. Episodes, 19:120-125.

Peccerillo, R. \& Taylor, S.R. 1976. Geochemistry of Eocene calcalkaline volcanic rocks from the Kastamonu area, northern Turkey. Contributions to Mineralogy and Petrology, 58:63-81.

Ruiz A.S. 2005. Evolução geológica do sudoeste do Cráton Amazônico região limítrofe Brasil-Bolívia - Mato Grosso [Geological evolution of southwestern Amazonian Craton, Brazil-Bolivia border region - Mato
Grosso]. Doctorate Thesis, Instituto de Geociências e Ciências Exatas, Universidade Estadual Paulista, 14-245 p.

Ruiz A.S., Matos J.B., Sousa M.Z.A., Lima G.A., Macambira M.B., Matos G.R., Faria D.A., França O., Costa P.C.C. 2012. Granites of Pensamiento Intrusive Suite: Records of the Continental Magmatic Arc San Ignacio in Brazil. In: VIII South American Symposium on Isotope Geology, 2012, Medellín. Anais do VIII South American Symposium on Isotope Geology.

Ruiz A.S., Sousa M.Z.A., Macambira M.B.; Lima G.A., Santos F. 2009. Evidências Geológicas e Geocronológicas (Pb-Pb e U-Pb) dos Episódios Magmáticos Lomas Manechis e San Ignácio no Terreno Paraguá - SW do Craton Amazônico - Vila Bela (MT) [Geological and Geochronological Evidence (Pb-Pb and U-Pb) of the Magmatic Episodes Lomas Manechis and San Ignácio in the Paraguá Terrane SW Amazonian Craton - Vila Bela (MT)]. In: Simpósio 45 Anos de Geocronologia no Brasil, São Paulo, Anais, p. 304-306.

Ruiz A.S., Sousa M Z.A., Matos J.B., Macambira M.B., Lima G.A., Faria D.A. 2011. Craton ou Terreno Paraguá? Uma discussão baseada em novos dados geológicos e geocronológicos do SW do Craton Amazônico em território brasileiro [Craton or Paraguá Terrane? A discussion based on new geological and geochronological data of the SW Amazonian Craton in Brazilian territory]. In: XIII Simpósio Nacional de Estudos Tectônicos, Campinas, Anais, p. 239-242.

Sato K., Basei M.A.S., Siga O.J., 2008. Novas técnicas aplicadas ao método U-Pb no CPGeo - IGc/USP: avanços na digestão química, espectrometria de massa (TIMS) e exemplos de aplicação integrada com SHRIMP [New techniques applied to U-Pb method at CPGeo Igc/USP: advances in chemical digestion, mass spectrometry (TIMS) and examples of application integrated with SHRIMP]. Geologia USP Série Científica, 8:77-99

Shand S.J. 1927. Eruptive Rocks. Their Genesis, Composition, Classification, and Their Relation to Ore-Deposits. London, 360 p.

Steiger R.H. \& Jäger, E. 1977. Subcommission on geochronology: convention on the use of decay constants in geo- and cosmochronology. Earth Planetary Science Letters. 36:359-362.

Stern R.A. 1998. High resolution SIMS determination of radiogenic trace isotope ratios in minerals. In: Cabri, L. J., Vaughan, D. J (Eds). Modern approaches to ore and environmental mineralogy. Mineralogical Association of Canada. Short Course Series, 27:241-268.

Williams I. 1998. U-Th-Pb geochronology by ion microprobe. In: McKibben M.A., Shanks III W.C., Ridley W.I., (eds.). Applications of microanalytical techniques to understanding mineralizing processes. Society of Economic Geologists. Short course, 7:1-35.

Arquivo digital disponível on-line no site www.sbgeo.org.br 